\title{
Hidden figures: A longitudinal analysis of the relationship between local context and beliefs about the causes of unemployment ${ }^{1}$
}

\author{
Daniel McArthur \\ daniel.mcarthur@politics.ox.ac.uk \\ Department of Politics and International Relations, University of Oxford, United Kingdom
}

September 2020

\begin{abstract}
Public support for the welfare state is shaped by beliefs about whether recipients are deserving or not. In the case of unemployed people, beliefs about whether they are at fault for their situation or not play a central role in shaping deservingness perceptions. Political actors and lay accounts suggest that living in disadvantaged places can shape attitudes towards welfare recipients. Existing research disagrees on whether higher local unemployment improves attitudes by providing information about the labour market, or worsens them by priming fears of welfare dependency. Thus, this study investigates whether individuals living in areas with higher unemployment benefit claims are more or less likely to believe that the unemployed are responsible for their situation. I innovate using a large sample of longitudinal data from the British Election Study to investigate the role of measuring unemployment benefit claims at multiple spatial scales, and over time. The results provide little evidence of a relationship between local unemployment and beliefs about the causes of unemployment, especially among affluent people. These findings challenge claims that antipathy towards unemployment benefits is shaped by exposure to unemployed people and undermine arguments that spatial segregation by income leads to decreased solidarity with the unemployed.
\end{abstract}

\footnotetext{
${ }^{1}$ The writing of this paper was supported by an ESRC PhD Studentship and the Jos Berghman Welfare Studies Stipend at KU Leuven. I thank Mike Savage, John Hills, Rob De Vries, Ursula Henz, Aaron Reeves, Ben Geiger, and Rebecca Noble for their comments on earlier versions. All remaining errors and omissions are my own. All data used in this paper is publicly available and Stata code allowing all analyses to be replicated will be made available online upon acceptance for publication.
} 


\section{Introduction}

'Where is the fairness, we ask, for the shift-worker, leaving home in the dark hours of the early morning, who looks up at the closed blinds of their next door neighbour sleeping off a life on benefits?' (George Osborne, then British Chancellor in 2012)

'A lot of people round here are living in poverty but I think a lot of it's their own doing. (Laura, 31, unemployed)' (Shildrick and MacDonald, 2013: 285).

Public support for redistribution and the welfare state is shaped by beliefs about whether welfare recipients are deserving or not (Aaroe and Petersen, 2014). Levels of support for the recipients of different kinds of benefits vary widely, with unemployment benefit recipients often regarded as relatively undeserving of help (Van Oorschot, 2006). Experimental studies find that the most important determinant is the extent to which claimants are responsible for their unemployment (Buss, 2019; Fong, 2007). Did they lose their previous job because of a recession or mass layoffs, or were they fired for low productivity? Are they actively searching for a new job or are they happy to live on benefits indefinitely?

This widespread uncertainty about the work ethic of the unemployed is reflected in high levels of popular support for welfare conditionality policies that sanction recipients for failure to comply with job search requirements (Buss, Ebbinghaus and Naumann, 2017). Policies such as the UK's recent Universal Credit reforms have what many observers consider to be punitive sanctioning regimes (Fletcher and Wright, 2018) that can exclude minorities (Schram, Fording and Soss, 2008) and harm the mental health of recipients (Wickham et al., 2020). In addition, negative stereotypes contribute to both the stigmatization faced by unemployed people, with resulting feelings of shame and inadequacy (Walker et al., 2013), as well as discrimination by employers, making it harder to return to work (Van Belle et al., 2018). As a result it is important to understand how people decide whether unemployed people are responsible for their situation or not.

One explanation for why individuals hold negative stereotypes about this group is that they have personally encountered unemployed people in the places they live who appear to be failing to 
look for work and living on benefits. This idea is popular among conservative critics of the welfare state who argue that popular antipathy to welfare recipients is legitimate in part because it is shaped by personal observations of individuals behaving in an undeserving manner (Baumberg, Bell and Gaffney, 2012). An example can be seen in the speech by George Osborne, the then British Chancellor of the Exchequer with which I begin this paper. Such views are also reported in qualitative work with people who are in poverty (see the second quote above), many of whom justify stigmatising views about others in poverty based on first-hand personal observation in their neighbourhood or town (Chase and Walker, 2012; Golding and Middleton, 1984; Shildrick and MacDonald, 2013). A very different view is found among researchers who are concerned that increasing socio-economic segregation by income has the potential to undermine the solidarity of the affluent with the disadvantaged (Bailey et al., 2013; Mijs, 2019; Thal, 2017). From their perspective, proximity to the unemployed leads advantaged people with little personal experience of poverty to increased knowledge of their living conditions and empathy with them.

I empirically interrogate these perspectives by investigating whether individuals who live in areas where unemployment benefits claims are more prevalent are more or less likely to believe that unemployed people are responsible for their situation. This study improves on existing research by drawing on the literature on contact with ethnic minorities and immigrants (Kaufmann and Goodwin, 2018) to measure area level unemployment benefit claims at multiple spatial scales and using longitudinal data to investigate the role of both levels and changes in claim rates. I analyse data from the British Election Study Panel Survey using random and fixed effects models.

My results provide no evidence for the view that those who blame the unemployed for their situation do so because of encounters with people who are failing to look for work or receiving undeserved benefits. The relationship between area level unemployment benefit claims and beliefs that that the unemployed are responsible for their situation is negative, substantively small, and not robust to potential confounders. Furthermore, to the extent that there is evidence for an association between unemployment benefit claims and beliefs that unemployed are not responsible for their situation, it is concentrated among the less well-off rather than the affluent - precisely the group whose attitudes should be less responsive to contact. Finally, there is no evidence that changes in unemployment benefit claims are associated with changes in attitudes towards the unemployed, though this finding will need to be replicated over longer time periods, 
and in contexts where unemployment rates shift more dramatically. One explanation for why local unemployment benefit claims play such a weak role in shaping attitudes is that unemployment is a hidden social status that is hard to discern in casual interactions in public places.

\section{Spatial segregation and beliefs about job loss}

While personal experience, influence from social networks, or media framings all influence attitudes towards the unemployed (Danckert, 2017; Golding and Middleton, 1984; Newman and Vickrey, 2017) there are good reasons for thinking that encounters with unemployment benefit claimants in your local area are also important. There is much evidence that encounters with ethnic minorities or immigrants can affect attitudes and political behaviour (Biggs and Knauss, 2012; Enos, 2016; Kaufmann and Goodwin, 2018), while local economic conditions affect perceptions of how the national economy is performing (Bisgaard, Dinesen and Sønderskov, 2016). Plausible mechanisms by which neighbourhood context could shape beliefs about the causes of unemployment include interpersonal observation in public spaces and territorial stigmatisation whereby awareness that areas are deprived shapes attitudes towards those who live in them (Galster, 2012). Thus, local encounters may shape beliefs about whether it is difficult to find a job or not, and whether unemployed people are actively searching for work.

Residential context is especially important because people's close relationships tend to be with those of similar social class. Hence interpersonal interaction in the local area is arguably a key venue for individuals from affluent and deprived backgrounds to interact and learn about one another. Drawing on this insight and recent findings that rising income inequality is associated with increased income segregation (Reardon and Bischoff, 2011), a number of scholars argue that greater spatial segregation by income is likely to lead to a decline in solidarity with the less well off on the part of the affluent (Bailey et al., 2013; Mijs, 2019; Thal, 2017). As a result they are committed to a well-known idea from contact theory that proximity to the less well-off increases sympathetic attitudes by debunking negative stereotypes and building empathy (Pettigrew, 1998).

There is some existing evidence supporting this idea: individuals whose family and friends experience unemployment become more supportive of unemployment benefits and more likely to believe that individuals are not at fault (Danckert, 2017; Hedegaard, 2014; Newman and Vickrey, 2017). Furthermore, affluent people who are more segregated from the poor believe that social 
conditions are better than affluent individuals in more economically diverse communities (Thal, 2017). These findings suggest that individuals living in areas with higher unemployment will be more aware of structural causes of job loss, and barriers to regaining work and hence less likely to believe that unemployed people in general are at fault for their situation. Similarly, when unemployment rises individuals are likely to revise up their expectations of how difficult it is to find work, and revise them down if unemployment falls.

This theoretical framework also suggests the effect of local unemployment on beliefs about the causes of unemployment will differ across individuals. Those who are more advantaged will have less awareness of unemployment from their personal experience and their social networks. As a result, even though they are likely to be less sympathetic towards the unemployed based on their personal experience, the affluent should be more responsive to local unemployment rates.

This discussion thus suggests two hypotheses:

Hypothesis 1: individuals in areas with higher unemployment benefit claims, or greater increases in unemployment benefit claims, will be less likely to believe that the unemployed are at fault for their situation.

Hypothesis 2: the association between area level unemployment benefit claims and the belief that the unemployed are responsible for their situation will be weaker for economically advantaged individuals.

\section{Proximity and fears about work ethic}

The literature reviewed above contrasts strongly with largely qualitative work which finds that people who are themselves in poverty and live in disadvantaged neighbourhoods often hold very negative perceptions of welfare recipients. There are many accounts of individuals drawing on the examples of their neighbours or local area to argue that welfare recipients abuse the system, or are otherwise undeserving because they fail to live up to social norms of respectability or hard work (Chase and Walker, 2012; Sennett and Cobb, 1972; Shildrick and MacDonald, 2013). In Golding and Middleton's classic study of welfare attitudes, 'personal experience' was the most common reason respondents gave for their views (1984: 173). 
This research suggests that higher local unemployment could actually provoke negative attitudes towards the unemployed. It could increase the belief that the unemployed are responsible for their situation. This is because widespread cultural stereotypes about unemployment may be more likely to be mobilized when unemployment is higher. In liberal welfare states such as the UK there are long-standing and deeply culturally entrenched ideas that the poor work ethic of the unemployed poses a threat to public finances, increasing competition for public services or the tax burden on those in work. There is some evidence that these stereotypes are differentially activated in times of high unemployment within the media (and possibly in public opinion) (Golding and Middleton, 1984; McArthur and Reeves, 2019). It is possible that individuals might respond to higher levels of local unemployment in the same manner. This suggests my third hypothesis:

Hypothesis 3: individuals in areas with higher unemployment benefit claims, or greater increases in unemployment benefit claims, will be more likely to believe that the unemployed are at fault for their situation.

\section{Why short-term, small changes may not matter}

There are good reasons for thinking that individual beliefs about the causes of unemployment will not always respond to changes in area level unemployment rates. Individuals' redistribution preferences are static over long periods in the absence of large economic shocks such as job loss (O'Grady, 2019). As a result, small changes in local unemployment benefit claims may not be sufficient to cause individuals to re-evaluate their attitudes towards unemployed people.

Furthermore, individual perceptions may not closely track actual levels of unemployment benefit claims. It is not necessarily possible to tell whether an individual is unemployed based on observation in public space, unlike other stigmatised statuses like ethnicity, national background, rough sleeping, and some disabilities. While often subject to misperceptions and inaccuracies, all of these social statuses can leave 'marks' on an individual that can be noticed by others who share social space with them (Goffman, 1968). By contrast, unemployment is much more hidden: unemployed people often hide their status from family and friends due to feelings of shame and fear of stigmatisation (Patrick, 2016). As a result, individual beliefs about the causes of unemployment may not respond to changes in unemployment benefit claims, especially if changes in claims are small or only take place over the short term. 


\section{Contribution to existing literature}

This article is the first to examine the relationship between area level unemployment and beliefs about whether the unemployed are responsible for their situation. In doing so I build on a small literature on the relationship between area level welfare receipt or poverty and attitudes towards people in poverty that offers few consistent findings (Bailey et al., 2013; Baumberg, 2015; Hopkins, 2009; Merolla, Hunt and Serpe, 2011). I improve upon it in four ways, adopting insights from the literature on how exposure to ethnic minorities and immigrants affects attitudes and political behavior.

Firstly, I measure local unemployment benefit claims at multiple scales because the association between exposure to an outgroup and attitudes towards that outgroup can vary dramatically depending on the spatial scale at which exposure is measured (Biggs and Knauss, 2012; Enos, 2016; Kaufmann and Goodwin, 2018). Secondly, individuals living in areas with long-term high immigrant populations are often more tolerant of immigrants, while those in which the immigrant share is increasing become less tolerant (Kaufmann, 2017). As a result this paper is the first to use longitudinal data to separately investigate levels of and changes in unemployment benefit claims. Thirdly, this longitudinal data allows me to use fixed-effects regression models to control for timeinvariant confounders such as the economic circumstances that survey respondents grew up in (O'Grady, 2019), which was not possible in previous research. Finally, I use data with a large sample size at individual and area levels (approximately 18,800 observations over 9,400 respondents), giving me substantial statistical power to detect an association if one exists.

\section{Data and variables}

I measure attitudes towards the unemployed using data for England and Wales from waves one and four of the British Election Survey Panel Study (BES), conducted in February 2014 and March 2015 respectively. The BES panel is a web survey, with respondents selected from YouGov's pool of survey takers by a form of quota sampling designed to ensure the achieved sample is representative of the population on a number of demographic characteristics (British Election Study, n.d.). This survey is the only publicly available panel survey that asks questions about attitudes towards the unemployed. It has a large sample size (approximately 18,800 observations 
over 9,400 respondents in my analyses) providing a good deal more statistical power than comparable studies.

I use the item 'when someone is unemployed, it is usually through no fault of their own' to measure the belief that the unemployed are responsible for their situation. Respondents who disagree are assumed to believe that unemployed people are usually at fault for losing their job or failing to find a new one. Respondents answer on a 5 point strongly agree to strongly disagree scale, where higher values indicate a more negative attitude toward the unemployed.

I measure unemployment benefit claims at two spatial scales: middle super output areas (MSOAs) and local authority districts (LAs). ${ }^{2}$ MSOAs are a unit of UK Census geography with an average population of $7,787(S D=1,600)$. They provide an approximation of an individual's neighbourhood, and have been used for this purpose in other studies of exposure to outgroups (Kaufmann, 2017). ${ }^{3}$ LAs are the smallest unit of local government in Britain, varying in population from around 20,000 to over 1 million ( mean $=161,600, S D=110,800)$.

My explanatory variable is the proportion of working age adults in an MSOA or LA who are receiving unemployment related benefits - known at the time in Britain as Jobseekers Allowance. I use unemployment benefit claims instead of unemployment rates because only the former are available on a time-varying basis at an MSOA scale. Due to a combination of eligibility restrictions and non-take up, unemployment benefit claims are typically a few percentage points lower than the unemployment rate, but highly correlated over time and space ( $r=0.93$ across LAs in my data). I average over the 3 months before the BES wave was fielded to smooth out short-term fluctuations. ${ }^{4}$

I control for a number of individual and area level variables that are likely to be correlated with area level unemployment benefit claims and influence beliefs about whether the unemployed are responsible for their situation. At an individual level I focus on measures of economic advantage.

\footnotetext{
${ }^{2}$ Individuals' locations are only observed when they enter the survey. Over the one year period of the study we would expect approximately $4.5 \%$ of the population to have changed addresses (Champion and Shuttleworth, 2017). As a result, residential migration is probably too infrequent to substantially bias results.

${ }^{3}$ The analysis focuses on respondents in England and Wales because Scotland's census geography does not include MSOAs.

${ }^{4}$ Data were obtained from Nomis, a repository of UK labour market statistics https://www.nomisweb.co.uk/.
} 
I control for work status (working, unemployed, in education, retired, and out of work for other reasons), self-reported poverty risk ( 5 point scale from very unlikely to very likely), and a dummy for the presence of activity limiting health conditions or disabilities.

Random effects models also include other variables that are only captured on entry to the panel. I use education (six levels from no qualifications to postgraduate education), and housing tenure (owner, private renter, social renter, living with family and friends) as further measures of economic advantage and also control for gender, age, ethnicity, marital status, and the presence of children. ${ }^{5}$ c control for area level affluence using median house prices and proportion of the working age population employed in professional-managerial occupations, the presence of minorities using the proportion of the population who are non-white, and population density (Bailey et al., 2013). House price data is time-varying and comes from the Office for National Statistics House Price Statistics for Small Areas (HPSSA) dataset, while class composition, the presence of minorities, and density are time-invariant and come from the 2011 Census. All area level controls are logged to deal with skewed distributions.

Descriptive statistics for beliefs about the causes of unemployment and unemployment benefit claims can be found in figure 1 , see tables $A 1$ and $A 2$ in the web appendix for all covariates. Missing values are deleted listwise, giving a total of 18,812 observations across 9,406 respondents in 4,912 MSOAs and 343 LAs.

\section{Regression models}

I use random effects and fixed effects linear regression models to explore the association between exposure to unemployment benefit claimants and beliefs that the unemployed are responsible for their situation. In all models the response variable is the belief that the unemployed are responsible for their situation, which I rescale to run from 0 to 100 so that the coefficient can be interpreted in percentage point terms. The main explanatory variable is area level unemployment benefit claims, measured at either MSOA or LA level. In all models I cluster standard errors by MSOA or LA to deal with the measurement of my explanatory variable at an area level and the

\footnotetext{
${ }^{5}$ Income is excluded from the analysis because it is only measured on entry to the panel and has many missing values.
} 
serial correlation of unemployment benefit claims as well as wave fixed effects to adjust for timevarying political or macroeconomic shocks that affect the entire country simultaneously.

Random effects models are used to investigate whether individuals who live in areas with high levels of unemployment benefit claims are more sympathetic towards the unemployed. They include individual-level random-intercepts as well as region fixed effects to adjust for timeinvariant disparities in regional economic context. Models with individual fixed effects are used to investigate the relationship between changes in area level unemployment benefits claims and changes in attitudes towards the unemployed. By using only over time variation in unemployment benefit claims these models remove the effects of all unmeasured time-invariant confounders.

\section{Results}

Figure 1 plots beliefs that the unemployed are responsible for their situation and the proportion claiming unemployment related benefits across MSOAs and LAs. I plot both levels and changes in these variables over the two waves studied. Panel (a) displays respondents' attitudes towards the unemployed. About $40 \%$ agree with the question that people become unemployed through no fault of their own, and about $20 \%$ disagree. Panel (b) shows the change in individual attitudes over time. About $50 \%$ of respondents did not change their views over the year between the two survey waves. About $8 \%$ of respondents transitioned from agreeing to disagreeing or vice versa, a substantial proportion given the short time scale over which the study was conducted. Panels (c) and (e) show the distribution of unemployment benefit claims over MSOAs and local authorities respectively. The mean proportion of the population claiming unemployment benefit is $2.3 \%$ (SD $=1.8$ ) for MSOAs and 2.1\% for LAs (SD = 1.2). Panels (e) and (f) suggest that unemployment benefit claims saw small declines in almost every area over the period of the study (MSOA: mean $=-0.85$, $S D=0.62, L A:$ mean $=-0.82, S D=0.38$ ). Changes in unemployment benefit claims appear highly correlated across areas - probably reflecting national trends in macroeconomic performance. I reflect on the implications of the small changes, and lack of increases in unemployment benefit claims in the discussion. 
a) Negative stereotypes about the unemployed

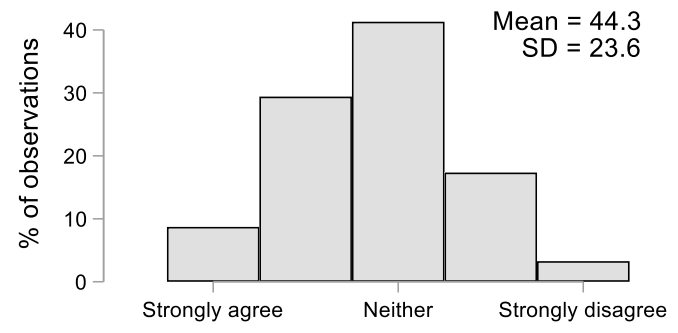

b) Change in negative stereotypes about the unemployed

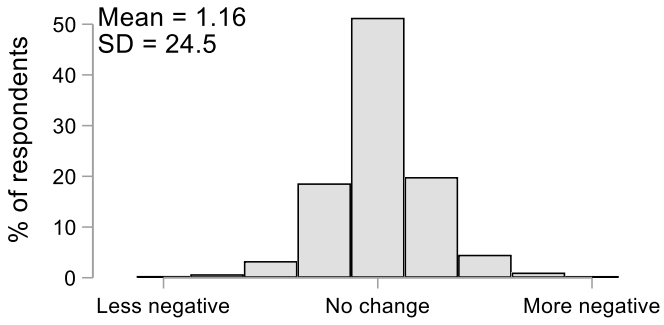

Percent of working age population claiming unemployment benefit

c) MSOA unemployment benefits claims

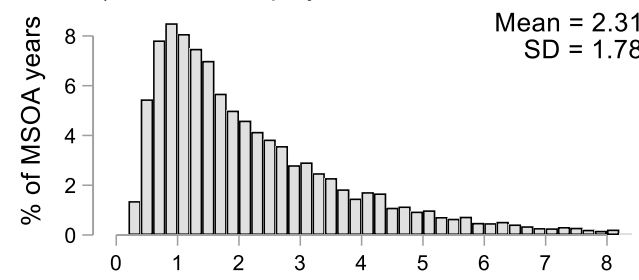

e) LA unemployment benefits claims

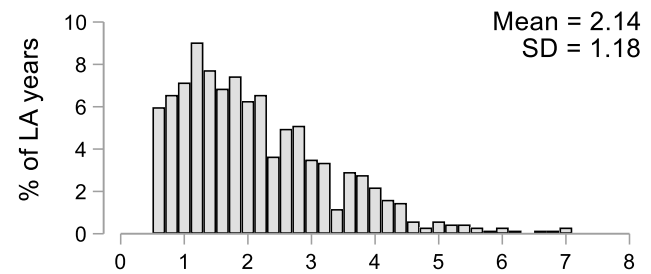

d) Change in MSOA unemployment benefit claims

$10-$ Mean $=-0.85$

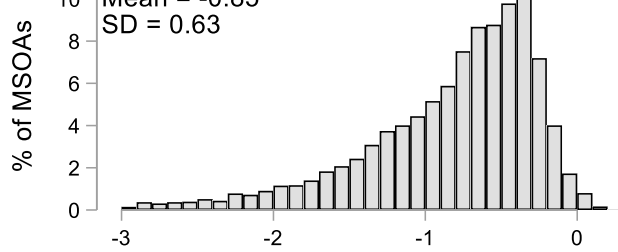

f) Change in LA unemployment benefit claims

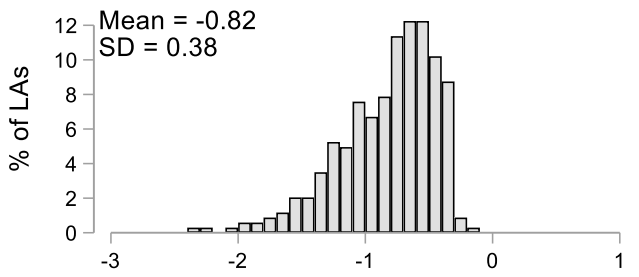

Figure 1: Levels of and changes in negative stereotypes about the unemployed and unemployment benefits claims at MSOA and LA levels. Panels (a) and (b) display negative stereotypes about the unemployed. Panels (c) - (f) display the proportion of the working age population receiving unemployment benefits. Panels (c) and (d) measure claims at MSOA level, panels (e) and (f) at LA level. Panels (a), (c), and (e) display the levels of each variable, while panels (b), (d), and (f) display changes over a one year period. 
Panel A of figure 2 displays estimates from random effects and fixed effects regression models of the association between area level unemployment benefit claims and beliefs that the unemployed are responsible for their situation. The left-hand plot measures exposure to the unemployed at MSOA level, and the right-hand plot at LA level. Model specification (2) introduces controls for individual economic position and demographics to adjust for differences between individuals living in areas with different levels of unemployment benefit claims. Specification (3) controls for area level affluence, diversity, and density to adjust for other features of areas correlated with unemployment benefit claims. Specification (4) includes all controls.

Turning first to the random effects models, the estimated association between local unemployment benefit claims is consistently negative in all specifications, and across MSOA and LA scales. The association between area level unemployment benefit claims and beliefs about the causes of unemployment is substantively weak: using estimates at an MSOA level with no controls, which has the largest coefficient estimate, a move from the $10^{\text {th }}$ percentile $(0.70 \%)$ to the $90^{\text {th }}$ percentile (4.65\%) of unemployment benefit claims is associated with only a 3.3 percentage point decrease in beliefs that the unemployed are not responsible for their situation. Furthermore, the inclusion of controls at both MSOA and LA levels reduces the size of the coefficient estimates and increases the width of confidence intervals. This suggests that a portion of the association is explained by individual socio-economic background (poorer people live in poorer places), and by area level differences in density, diversity, or affluence. As a result, the models which include both individual and area level controls at both MSOA and LA level have 90 and $95 \%$ confidence intervals consistent with both a small positive and a small negative association. Thus, these results provide only weak evidence for hypothesis 1 , and none for hypothesis 3.

The fixed effects estimates further weaken the evidence for both hypothesis 1 and hypothesis 3. Most of the point estimates are negative. However, the $95 \%$ and $90 \%$ confidence intervals are very wide, especially at a local authority level, and consistent with changes in unemployment benefit claims being associated with both higher and lower levels of belief that the unemployed are responsible for their situation. As a result, there is little reason to think, at least over the time period covered, that changes in unemployment benefit claims have any systematic relationship to beliefs about the causes of unemployment. Of course, given the short time period over which changes are observed and the relatively small changes in unemployment benefit claims, it is not clear how generalisable this finding is to other contexts. 
In order to check that the results above are not an artefact of the specific question chosen I reestimate the models from figure 2 using as a response variable answers to an item measuring perceived welfare dependency: 'Too many people these days like to rely on government handouts'. Panel B of figure 2 displays the results, focusing only on the models with only wave/region fixed effects and those with all covariates. Coefficient estimates are once again negative in all models. However, the association is once again substantively small, and non-robust to the inclusion of individual fixed effects. These results thus reinforce the main conclusions presented above. 


\section{A) Belief that unemployed responsible for situation}

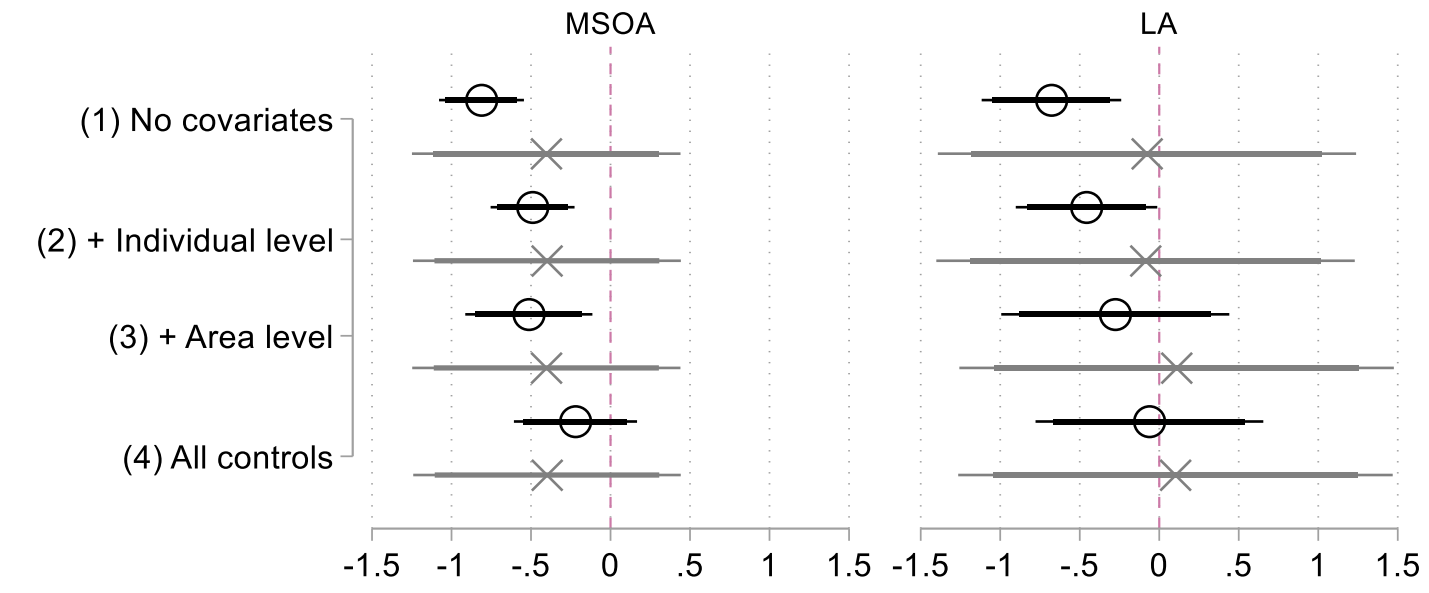

Coefficient of area level unemployment benefit claims on belief that unemployed responsible for their situation

Model: $\bigcirc$ Random effects $\times$ Fixed effects

\section{B) Perceived welfare dependency}

(1) No covariates

(4) All controls
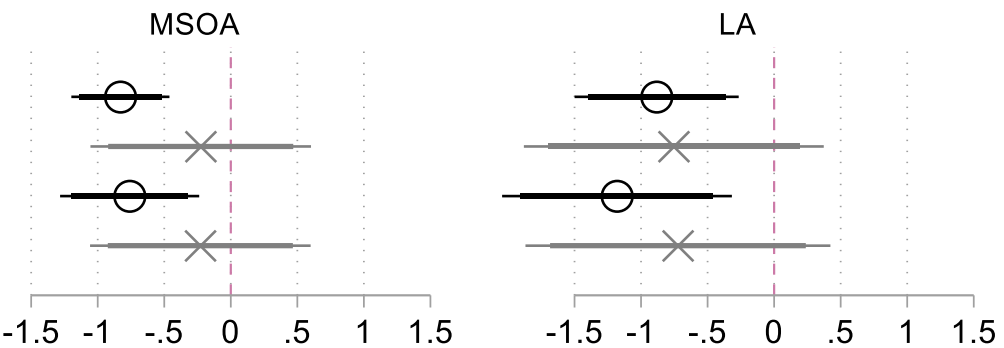

Coefficient of area level unemployment benefit claims on perception of welfare dependency

Figure 2: Association between unemployment benefit claims and belief that unemployed responsible for their situation (panel A) or perception of welfare dependency (panel B). Estimates and $95 \%$ and $90 \%$ confidence intervals from linear regression models with wave fixed effects and standard errors clustered at area level (either MSOA or LA). All random effects models include individual random intercepts and region controls, fixed effects models include individual fixed effects. Sample size $=18,812$ for models in panel A, 18,664 for models in panel B. Full regression tables in table A3-A5 in web appendix. 
To investigate whether the relationship between exposure to unemployment benefit claimants and attitudes towards the unemployed is stronger among more advantaged individuals I interact area-level unemployment benefits claims with indicators of individual economic advantage. I focus on two time-varying measures, work status and subjective perceptions of the likelihood of poverty, and one time-invariant measure, whether respondents are educated to degree level or not. Figure 3 displays estimated marginal means from random effects models with year and region fixed effects. The left-hand panel displays interactions with MSOA level unemployment benefit claims, the right-hand panel with LA level claims. Results tables are in table A6 in web appendix 2, alongside an additional analysis (Figure A1, table A7) showing that the substantive conclusions do not change when individual and area level controls are included in the model.

The association between area level unemployment benefit claims and beliefs about the causes of poverty is either negative or flat across all levels of economic position. This provides further evidence against hypothesis 3 . However, the relationship is consistently more negative among disadvantaged individuals, whether unemployed or not in the labour force, compared to those working (panels $a$ and $b$ ), those experiencing a very high level of subjective poverty risk compared to those who are not (panels $\mathrm{c}$ and d), and those with at least degree level education compared to those with less education (panels e and f). These results are inconsistent with hypothesis 2, the idea that the affluent respond more strongly than the disadvantaged to local unemployment by becoming more sympathetic. 

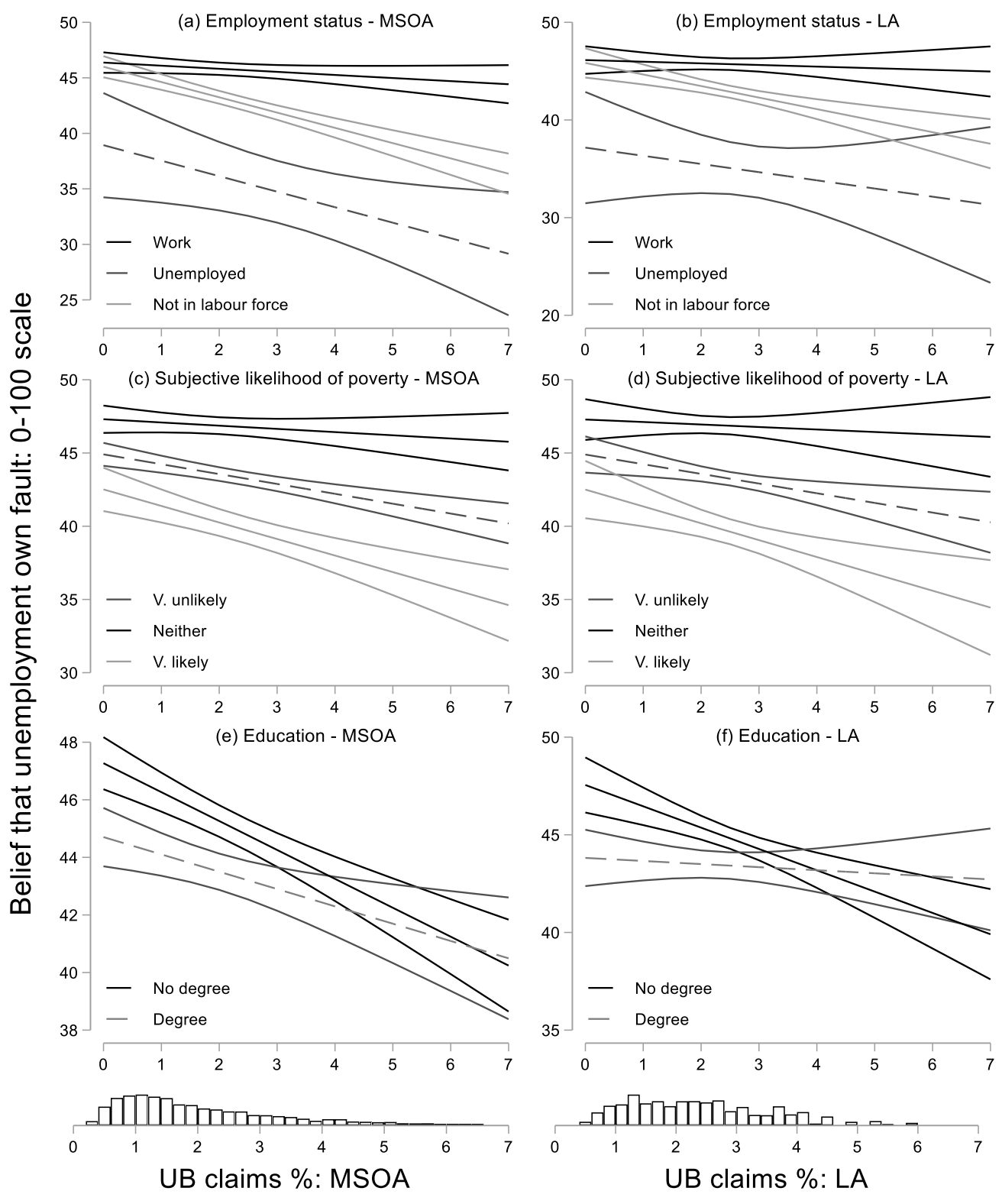

Figure 3: Association between unemployment benefit claims and belief that unemployed responsible for situation conditional on economic advantage. Estimated marginal means and $95 \%$ confidence intervals from random effects regression models with random intercepts for individuals, wave and region fixed effects, and standard errors clustered at area level (either MSOA or LA). Sample size $=18,812$. Full regression tables in table A4, web appendix 2. Bottom panels display histograms of unemployment benefit claims. 


\section{Discussion}

This paper investigates the relationship between unemployment benefit claims and beliefs that the unemployed are responsible for their situation. The results provide very little evidence that higher local unemployment is associated with a belief that the unemployed are responsible for their situation. They are not much more supportive of the idea that proximity to the unemployed promotes sympathy by revealing local labour market difficulties and hence shaping beliefs that the unemployed are not responsible for their situation. Individuals living in areas with higher unemployment benefit claims are less likely to believe that unemployed are at fault for their situation (and also less likely to perceive welfare dependency). However, this association is to a large extent explained away by compositional differences. Furthermore, there is no evidence that changes in unemployment benefit claims are associated with changes in beliefs about the causes of unemployment. These results have commonalities with some existing research on attitudes towards welfare recipients, which also find weak evidence for the role of local context (Bailey et al., 2013; Hopkins, 2009). This analysis adds additional weight to these conclusions with a larger sample size and data at multiple spatial scales. The comparatively hidden nature of unemployment compared to membership of some other stigmatised statuses that leave directly observable 'marks' may provide a partial explanation for why this study differs from those finding evidence that area-level exposure to ethnic minorities, immigrants, or street homeless affects attitudes (Enos, 2016; Kaufmann and Goodwin, 2018; Lee, Farrell and Link, 2004).

These results contribute to a debate on how income inequality affects individual attitudes towards the poor and welfare recipients. They provide evidence against the idea that higher economic inequality worsens solidarity with the poor and welfare recipients by increasing residential segregation (Bailey et al., 2013; Mijs, 2019; Thal, 2017). This theory is built on the presupposition that greater exposure to the poor or welfare recipients improves perceptions among advantaged people whose personal experience of economic hardship is likely to be low. However, I find that the attitudes of the affluent actually vary to the same or a lesser extent across area contexts than those of the disadvantaged - inconsistent with the idea that greater exposure to the unemployed should improve attitudes the most among the affluent. One implication of these findings is for debates about the extent to which promoting greater social mix in housing, and hence decreasing economic segregation, will promote solidarity with disadvantaged groups such as the unemployed (Bailey et al., 2013). While higher neighbourhood exposure to 
unemployment benefit recipients is unlikely to cause a backlash against this group, it doesn't seem to promote sympathy amongst the affluent either. While there are many good reasons to advocate for greater social mix in housing and other policies to reduce socio-economic segregation, shaping attitudes towards welfare recipients may not be one of them (Mayer, 2002).

\section{Limitations and generalisability}

Some limitations of the data constrain the generalizability of my findings. I looked at changes in unemployment benefit claims over a short period of time in which levels of unemployment benefit claims declined across the country from an already low base. As a result, it is possible that individuals did not have a long enough period to change their attitudes towards the unemployed and that changes in unemployment benefit claims were not large enough to meaningfully alter levels of exposure to claimants. Concerns about the short time period are partially allayed by the finding that although the study was carried out over a short time period, a non-negligible share $(8 \%)$ of respondents changed their views about the unemployed. Furthermore, this study has a much larger sample size at the individual level (18800 observations over 9400 individuals) than existing research (Bailey et al., 2013; Baumberg, 2015; Hopkins, 2009; Merolla, Hunt and Serpe, 2011) and a substantial sample size at MSOA and LA levels, likely giving it adequate power to detect even a small association between unemployment benefits claims and beliefs about the causes of unemployment.

However, the generalizability of my findings to longer periods of exposure, higher levels of and greater changes in unemployment benefit claims are unknown. High levels or large changes in unemployment benefits claims may have a meaningful effect on individual attitudes, especially when accompanied by highly visible social consequences such as queues outside unemployment offices and soup kitchens. As a result the findings of this paper can be best thought of as evidence against a strong effect of exposure to unemployment benefit claimants on beliefs about the causes of unemployment that operates in contexts of relatively low unemployment benefit claims and over relatively short time periods.

At the time of writing, the economic fallout of the coronavirus pandemic has caused an 
unprecedented surge in unemployment benefit claims in many countries. ${ }^{6}$ While it is too early to be certain, this situation may be important for understanding how major recessions shape public support for unemployment benefits. However, this crisis may not be especially informative regarding the role of purely local unemployment rates, as opposed to national economic context mediated through the media or political discourse, if claim rates rise dramatically in all areas under study, giving little between area variation. As a result, the research design developed in this article, with time fixed effects to control for spatially invariant shocks, and analyses conducted at multiple scales, presents a useful model for future longitudinal research over what looks likely to be a period of high and volatile unemployment rates.

\section{Conclusions}

Public perceptions of whether unemployed people are responsible for their situation or not are crucial for understanding the political legitimacy of unemployment benefits, as well as the stigmatization that workless individuals often face. Using data from The British Election Study Panel Survey, I analyse the association between area-level unemployment benefit claims and beliefs that the unemployed are responsible for their situation. I build on previous research in this area by measuring unemployment benefit claims at multiple spatial scales, and looking at the role of both changes and levels in claims. My results provide no evidence at all for the view (exemplified by the George Osborne quote with which I began this paper) that beliefs that unemployed people are undeserving stems mainly from observations of people who are failing to look for work. Individuals who live in areas with higher levels of unemployment are generally less likely to believe that the unemployed are at fault for their situation. However, this relationship is both small in substantive size and not robust to controls for individual economic position or area context. As a result there is also little evidence for the perspective that greater exposure to the unemployed will lead to more sympathetic beliefs about their work ethic, especially in the case of affluent individuals. These results thus cast doubt on the idea that lower socioeconomic segregation will lead to greater solidarity with welfare recipients. A possible explanation for this surprisingly weak relationship is that unemployment is a hidden status that is hard to discern in casual interactions. Thus, policy initiatives to decrease economic segregation by promoting social

\footnotetext{
${ }^{6}$ e.g. for the UK https://www.itv.com/news/2020-04-02/covid-19-almost-950-000-people-apply-foruniversal-credit-in-two-weeks/.
} 
mix in housing are unlikely to lead to a backlash against the unemployed on the part of the affluent, but neither do they seem likely to promote greater understanding either. Future research should investigate how these findings generalize to contexts with greater changes in unemployment such as the onset of major recessions. 


\section{Bibliography}

Aaroe, Lene and Michael Bang Petersen (2014) Crowding out culture: Scandinavians and Americans agree on social welfare in the face of deservingness cues. Journal of Politics 76(3): 684-697.

Bailey, Nick, Maria Gannon, Ade Kearns, Mark Livingston and Alastair H Leyland (2013) Living Apart, Losing Sympathy? How Neighbourhood Context Affects Attitudes to Redistribution and to Welfare Recipients. Environment and Planning A 45(9): 2154-2175.

Baumberg, Ben (2015) The stigma of claiming benefits: A quantitative study. Journal of Social Policy 45(2): 181-199.

Baumberg, Ben, Kate Bell and Declan Gaffney (2012) Benefits Stigma in Britain. London: Turn 2 Us.

Biggs, Michael and Steven Knauss (2012) Explaining membership in the British National Party: A multilevel analysis of contact and threat. European Sociological Review 28(5): 633-646.

Bisgaard, Martin, Peter Thisted Dinesen and Kim Mannemar Sønderskov (2016) Reconsidering the Neighborhood Effect: Does Exposure to Residential Unemployment Influence Voters' Perceptions of the National Economy? The Journal of Politics 78(3): 719-732.

British Election Study (n.d.) BES 2015 Wave 7 Questionnaire. Available at: https://www.britishelectionstudy.com/wpcontent/uploads/2018/09/Bes_wave14Documentation_V1.pdf.

Buss, Christopher (2019) Public opinion towards targeted labour market policies: A vignette study on the perceived deservingness of the unemployed. Journal of European Social Policy 29(2): 228240.

Buss, Christopher, Bernhard Ebbinghaus and Elias Naumann (2017) Making deservingness of the unemployed conditional: changes in public support for the conditionality of unemployment benefits. In: Van Oorschot W, Roosma F, Meuleman B, et al. (eds) The Social Legitimacy of Targeted Welfare: Attitudes to Welfare Deservingness. Cheltenham: Edward Elgar, pp. 167188.

Champion, Tony and lan Shuttleworth (2017) Are People Changing Address Less? An Analysis of Migration within England and Wales, 1971-2011, by Distance of Move. Population, Space and Place 23(3).

Chase, Elaine and Robert Walker (2012) The Co-construction of Shame in the Context of Poverty: 
Beyond a Threat to the Social Bond. Sociology 47(4): 739-754.

Danckert, Bolette (2017) Facing Unemployment: Personal and Vicarious Unemployment Experiences Generate Favourable Perceptions of Unemployed People. European Sociological Review 33(6): 779-790.

Enos, Ryan D (2016) What the Demolition of Public Housing Teaches Us about the Impact of Racial Threat on Political Behavior. American Journal of Political Science 60(1): 123-142.

Fletcher, Del Roy and Sharon Wright (2018) A hand up or a slap down? Criminalising benefit claimants in Britain via strategies of surveillance, sanctions and deterrence. Critical Social Policy 38(2): 323-344.

Fong, Christina M (2007) Evidence from an experiment on charity to welfare recipients: reciprocity, altruism and the empathic responsiveness hypothesis. Economic Journal 117(522): 1008-1024.

Galster, George C (2012) The mechanism(s) of neighbourhood effects: theory, evidence, and policy implications. In: Van Ham M, Manley D, Bailey N, et al. (eds) Neighbourhood Effects Research: New Perspectives. Dordrecht: Springer.

Goffman, Erving (1968) Stigma: Notes on the Management of Spoiled Identity. Harmondsworth, UK: Penguin.

Golding, Peter and Sue Middleton (1984) Images of Welfare: Press and Public Attitudes to Poverty. Oxford: Basil Blackwell.

Hedegaard, Troels Fage (2014) The policy design effect: Proximity as a micro-level explanation of the effect of policy designs on social benefit attitudes. Scandinavian Political Studies 37(4): $366-$ 384.

Hopkins, Daniel J (2009) Partisan reinforcement and the poor: The impact of context on explanations for poverty. Social Science Quarterly 90(3): 744-764.

Kaufmann, Eric (2017) Levels or changes?: Ethnic context, immigration and the UK Independence Party vote. Electoral Studies 48: 57-69.

Kaufmann, Eric and Matthew J Goodwin (2018) The diversity wave: A meta-analysis of the nativeborn white response to ethnic diversity. Social Science Research 76: 120-131.

Lee, Barrett A, Chad R Farrell and Bruce G Link (2004) Revisiting the Contact Hypothesis: The Case of Public Exposure to Homelessness. American Sociological Review 69(1): 40-63. 
Mayer, Susan E (2002) How Economic Segregation Affects Children's Educational Attainment. Social Forces 81(1): 153-176.

McArthur, Daniel and Aaron Reeves (2019) The Rhetoric of Recessions: How British Newspapers Talk about the Poor When Unemployment Rises, 1896-2000. Sociology 53(6): 1005-1025.

Merolla, David M, Matthew O Hunt and Richard T Serpe (2011) Concentrated Disadvantage and Beliefs about the Causes of Poverty: A Multi-Level Analysis. Sociological Perspectives 54(2): 205-228.

Mijs, Jonathan JB (2019) The paradox of inequality: income inequality and belief in meritocracy go hand in hand. Socio-Economic Review: 1-29. DOI:10.1093/ser/mwy051.

Newman, Benjamin J and Clifford D Vickrey (2017) Friends on the Dole: Social networks, vicarious economic distress, and support for social welfare spending. International Journal of Public Opinion Research 29(1): 172-188.

O'Grady, Tom (2019) How do Economic Circumstances Determine Preferences? Evidence from Longrun Panel Data. British Journal of Political Science 49(4): 1381-1406.

Osborne, George (2012) George Osborne's speech to the Conservative conference: full text. Available at: https://www.newstatesman.com/blogs/politics/2012/10/george-osbornesspeech-conservative-conference-full-text.

Patrick, Ruth (2016) Living with and responding to the 'scrounger' narrative in the UK: exploring everyday strategies of acceptance, resistance and deflection. The Journal of Poverty and Social Justice 24(3): 245-259.

Pettigrew, Thomas F (1998) Intergroup Contact Theory. Annual Review of Psychology 49(1): 65-85.

Reardon, Sean F and Kendra Bischoff (2011) Income inequality and income segregation. American Journal of Sociology 116(4): 1092-1153.

Schram, Sanford F, Richard C Fording and Joe Soss (2008) Neo-liberal poverty governance: Race, place and the punitive turn in US welfare policy. Cambridge Journal of Regions, Economy and Society 1: 17-36.

Sennett, Richard and Jonathan Cobb (1972) The Hidden Injuries of Class. Cambridge: UK: Cambridge University Press.

Shildrick, Tracy and Robert MacDonald (2013) Poverty talk: how people experiencing poverty deny 
their poverty and why they blame 'the poor'. The Sociological Review 61(2): 285-303.

Thal, Adam (2017) Class Isolation and Affluent Americans' Perception of Social Conditions. Political Behavior 39(2): 401-424.

Van Belle, Eva, Valentina Di Stasio, Ralf Caers, Marijke De Couck and Stijn Baert (2018) Why Are Employers Put Off by Long Spells of Unemployment? European Sociological Review 34(6): 694710.

Van Oorschot, Wim (2006) Making the difference in social Europe: deservingness perceptions among citizens of European welfare states. Journal of European Social Policy 16(1): 23-42.

Walker, Robert, Grace Bantebya Kyomuhendo, Elaine Chase et al. (2013) Poverty in Global Perspective: Is Shame a Common Denominator? Journal of Social Policy 42(2): 215-233.

Wickham, Sophie, Lee Bentley, Tanith Rose, Margaret Whitehead, David Taylor-Robinson and Ben Barr (2020) Effects on mental health of a UK welfare reform, Universal Credit: a longitudinal controlled study. The Lancet Public Health 5(3): e157-e164. 


\section{Web appendices}

Hidden figures: a longitudinal analysis of the relationship between local context and beliefs about the causes of unemployment

This web appendix contains tables of descriptive statistics for all variables used in the analysis, the underlying regression models from which figures 2 and 3 were created, and some additional robustness checks. 


\section{CONTENTS}

\section{Tables}

Table A1: Descriptive statistics for time varying variables

Table A2: Descriptive statistics for all time-invariant covariates

Table A3: Association between unemployment benefit claims at MSOA level and belief that unemployed responsible for their situation. Coefficients plotted in figure 2.

Table A4: Association between unemployment benefit claims at LA level and belief that unemployed responsible for their situation. Coefficients plotted in figure 2 .

Table A5: Association between unemployment benefit claims and perceived welfare dependency. Coefficients plotted in figure 2 .

Table A6: Association between unemployment benefit claims and belief that unemployed responsible for situation conditional on economic advantage. Estimated marginal means plotted in figure 3.

Table A7: Association between unemployment benefit claims and belief that unemployed responsible for situation conditional on economic advantage with individual and area level controls. Estimated marginal means plotted in figure A1.

\section{Figures}

Figure A1: Association between unemployment benefit claims and belief that unemployed responsible for situation conditional on economic advantage with individual and area level controls. 
Table A1: Descriptive statistics for time varying variables

\begin{tabular}{|c|c|c|c|c|c|c|c|c|}
\hline \multirow[b]{2}{*}{ Variable } & \multicolumn{2}{|c|}{ FEBRUARY 2014} & \multirow[b]{2}{*}{ Min } & \multirow[b]{2}{*}{ Max } & \multicolumn{2}{|c|}{ MARCH 2015} & \multirow[b]{2}{*}{ Min } & \multirow[b]{2}{*}{ Max } \\
\hline & Mean & Std. Dev. & & & Mean & Std. Dev. & & \\
\hline \multicolumn{9}{|l|}{ RESPONSE VARIABLES } \\
\hline $\begin{array}{l}\text { When someone is unemployed, it is usually through } \\
\text { no fault of their own (reversed) }\end{array}$ & 43.7 & 23.5 & 0 & 100 & 44.8 & 23.7 & 0 & 100 \\
\hline $\begin{array}{l}\text { Too many people these days like to rely on } \\
\text { government handouts }\end{array}$ & 66.0 & 29.6 & 0 & 100 & 67.2 & 29.6 & 0 & 100 \\
\hline \multicolumn{9}{|l|}{ UNEMPLOYMENT BENEFIT CLAIMS } \\
\hline Unemployment benefit claims - MSOA & 2.67 & 1.87 & 0.30 & 17.11 & 1.85 & 1.36 & 0.12 & 11.35 \\
\hline Unemployment benefit claims - LA & 2.87 & 1.27 & 0.80 & 7.03 & 1.98 & 0.95 & 0.50 & 4.97 \\
\hline \multicolumn{9}{|l|}{ TIME VARYING COVARIATES } \\
\hline Subjective likelihood of poverty & 2.51 & 1.30 & 1 & 5 & 2.38 & 1.27 & 1 & 5 \\
\hline Work & 0.52 & 0.50 & 0 & 1 & 0.51 & 0.50 & 0 & 1 \\
\hline Unemployed & 0.02 & 0.15 & 0 & 1 & 0.01 & 0.11 & 0 & 1 \\
\hline Education & 0.01 & 0.12 & 0 & 1 & 0.01 & 0.09 & 0 & 1 \\
\hline Retired & 0.36 & 0.48 & 0 & 1 & 0.38 & 0.48 & 0 & 1 \\
\hline Not in paid work & 0.09 & 0.29 & 0 & 1 & 0.09 & 0.28 & 0 & 1 \\
\hline \multicolumn{9}{|l|}{ Disabilities limiting daily life } \\
\hline No & 0.67 & 0.47 & 0 & 1 & 0.73 & 0.44 & 0 & 1 \\
\hline Yes & 0.33 & 0.47 & 0 & 1 & 0.27 & 0.44 & 0 & 1 \\
\hline Log house prices - MSOA & 12.23 & 0.42 & 11.3 & 14.3 & 12.3 & 0.4 & 11.4 & 14.5 \\
\hline Log house prices - LA & 12.18 & 0.49 & 10.8 & 14.6 & 12.3 & 0.5 & 10.8 & 14.8 \\
\hline
\end{tabular}


Notes: Sample size $=18,812$ observations across 9,406 respondents in 4,912 MSOAs and 343 LAs for all variables except "Too many people these days like to rely on government handouts". For this variable, sample size $=18,664$ observations across 9,400 respondents in 4,911 MSOAs and 343 LAs. Individual level data from BES panel survey waves 1 (Feb 2014) and 4 (March 2015). Unemployment benefit claims data from Nomis, house prices from ONS HPPSA. Means for categorical variables represent proportion falling into category. 
Table A2: Descriptive statistics for all time-invariant covariates

\begin{tabular}{|c|c|c|c|c|}
\hline & Mean & Std. Dev. & Min & Max \\
\hline Age & 55.29 & 13.63 & 18 & 95 \\
\hline \multicolumn{5}{|l|}{ Gender } \\
\hline Male & 0.51 & 0.50 & 0 & 1 \\
\hline Female & 0.49 & 0.50 & 0 & 1 \\
\hline \multicolumn{5}{|l|}{ Education } \\
\hline No qualifiations & 0.09 & 0.29 & 0 & 1 \\
\hline Below GCSE & 0.06 & 0.23 & 0 & 1 \\
\hline GCSE & 0.24 & 0.43 & 0 & 1 \\
\hline A-level & 0.19 & 0.39 & 0 & 1 \\
\hline Undergraduate & 0.33 & 0.47 & 0 & 1 \\
\hline Postgraduate & 0.11 & 0.31 & 0 & 1 \\
\hline \multicolumn{5}{|l|}{ Housing tenure } \\
\hline Owner & 0.78 & 0.41 & 0 & 1 \\
\hline Private renter & 0.08 & 0.27 & 0 & 1 \\
\hline Social renter & 0.10 & 0.30 & 0 & 1 \\
\hline Family/friends & 0.04 & 0.19 & 0 & 1 \\
\hline \multicolumn{5}{|l|}{ Marital status } \\
\hline Married & 0.70 & 0.46 & 0 & 1 \\
\hline Divorced & 0.11 & 0.31 & 0 & 1 \\
\hline Widowed & 0.04 & 0.20 & 0 & 1 \\
\hline Never married & 0.15 & 0.36 & 0 & 1 \\
\hline \multicolumn{5}{|c|}{ Children in household } \\
\hline No & 0.81 & 0.39 & 0 & 1 \\
\hline Yes & 0.19 & 0.39 & 0 & 1 \\
\hline \multicolumn{5}{|l|}{ Ethnicity } \\
\hline White & 0.96 & 0.19 & 0 & 1 \\
\hline Mixed & 0.01 & 0.09 & 0 & 1 \\
\hline Asian & 0.01 & 0.12 & 0 & 1 \\
\hline Black & 0.01 & 0.08 & 0 & 1 \\
\hline Other & 0.01 & 0.08 & 0 & 1 \\
\hline \multicolumn{5}{|l|}{ Religion } \\
\hline None & 0.40 & 0.49 & 0 & 1 \\
\hline Church of England & 0.38 & 0.48 & 0 & 1 \\
\hline Catholic & 0.09 & 0.28 & 0 & 1 \\
\hline Other Christian & 0.07 & 0.25 & 0 & 1 \\
\hline Jewish & 0.01 & 0.11 & 0 & 1 \\
\hline Muslim & 0.01 & 0.08 & 0 & 1 \\
\hline Other & 0.05 & 0.21 & 0 & 1 \\
\hline
\end{tabular}




\begin{tabular}{|c|c|c|c|c|}
\hline Log professional managerial share - MSOA & 2.26 & 0.33 & 1.39 & 3.57 \\
\hline Log share non-white - MSOA & 1.93 & 1.07 & 0.07 & 4.26 \\
\hline Log Density - MSOA & 2.12 & 1.40 & -1.61 & 4.93 \\
\hline Log professional managerial share - LA & 2.22 & 0.53 & -0.02 & 3.57 \\
\hline Log share non-white - LA & 1.71 & 1.15 & -0.69 & 4.53 \\
\hline Log Density - LA & 2.62 & 1.54 & -2.30 & 5.51 \\
\hline \multicolumn{5}{|l|}{ Region } \\
\hline East & 0.10 & 0.30 & 0 & 1 \\
\hline East Midlands & 0.07 & 0.26 & 0 & 1 \\
\hline London & 0.14 & 0.35 & 0 & 1 \\
\hline North East & 0.04 & 0.18 & 0 & 1 \\
\hline North West & 0.11 & 0.31 & 0 & 1 \\
\hline South East & 0.15 & 0.36 & 0 & 1 \\
\hline South West & 0.09 & 0.29 & 0 & 1 \\
\hline Wales & 0.12 & 0.33 & 0 & 1 \\
\hline West Midlands & 0.08 & 0.28 & 0 & 1 \\
\hline Yorkshire & 0.09 & 0.29 & 0 & 1 \\
\hline
\end{tabular}

Notes: Sample size $=18,812$ observations across 9,406 respondents in 4,912 MSOAs and 343 LAs for all variables. Individual level data from BES panel survey waves 1 (Feb 2014) and 4 (March 2015). Area level variables from 2011 Census. Means for categorical variables represent proportion falling into category. 
Table A3: Association between unemployment benefit claims at MSOA level and belief that unemployed responsible for their situation. Coefficients plotted in figure 2.

\begin{tabular}{|c|c|c|c|c|c|c|c|c|}
\hline \multirow[b]{3}{*}{ Model } & (1) & (2) & (3) & (4) & (5) & (6) & (7) & (8) \\
\hline & \multicolumn{2}{|c|}{ No covariates } & \multicolumn{2}{|c|}{ + Individual level } & \multicolumn{2}{|c|}{ + Area level } & \multicolumn{2}{|c|}{ All covariates } \\
\hline & RE & $\mathrm{FE}$ & RE & $\mathrm{FE}$ & RE & $\mathrm{FE}$ & RE & $\mathrm{FE}$ \\
\hline \multirow{2}{*}{$\begin{array}{l}\text { Unemployment benefit claims - } \\
\text { MSOA }\end{array}$} & $-0.81^{* * *}$ & -0.40 & $-0.49^{* * *}$ & -0.40 & $-0.51^{*}$ & -0.40 & -0.22 & -0.40 \\
\hline & {$[-1.08,-0.54]$} & {$[-1.25,0.44]$} & {$[-0.75,-0.23]$} & {$[-1.24,0.44]$} & {$[-0.91,-0.11]$} & {$[-1.25,0.44]$} & {$[-0.61,0.17]$} & {$[-1.24,0.44]$} \\
\hline \multirow[t]{2}{*}{ Subjective poverty risk } & & & $-1.42^{* * *}$ & -0.29 & & & $-1.42^{* * *}$ & -0.29 \\
\hline & & & {$[-1.74,-1.10]$} & {$[-0.79,0.20]$} & & & {$[-1.74,-1.10]$} & {$[-0.78,0.21]$} \\
\hline \multirow[t]{2}{*}{ Economic activity (ref=working) } & & & 0.00 & 0.00 & & & 0.00 & 0.00 \\
\hline & & & {$[0.00,0.00]$} & {$[0.00,0.00]$} & & & {$[0.00,0.00]$} & {$[0.00,0.00]$} \\
\hline \multirow[t]{2}{*}{ Unemployed } & & & $-9.08^{* * *}$ & -0.58 & & & $-9.11^{* * *}$ & -0.60 \\
\hline & & & {$[-11.87,-6.29]$} & {$[-4.47,3.31]$} & & & {$[-11.90,-6.32]$} & {$[-4.49,3.28]$} \\
\hline \multirow[t]{2}{*}{ Education } & & & -1.81 & 2.03 & & & -1.77 & 2.04 \\
\hline & & & {$[-5.44,1.82]$} & {$[-3.19,7.26]$} & & & {$[-5.41,1.88]$} & {$[-3.18,7.27]$} \\
\hline \multirow[t]{2}{*}{ Retired } & & & -0.11 & -1.41 & & & -0.13 & -1.44 \\
\hline & & & {$[-1.17,0.94]$} & {$[-3.76,0.95]$} & & & {$[-1.18,0.93]$} & {$[-3.79,0.91]$} \\
\hline \multirow[t]{2}{*}{ Not in paid work } & & & $-6.06^{* * *}$ & -1.44 & & & $-6.08^{* * *}$ & -1.48 \\
\hline & & & {$[-7.48,-4.64]$} & {$[-4.28,1.40]$} & & & {$[-7.50,-4.66]$} & {$[-4.32,1.36]$} \\
\hline \multirow[t]{2}{*}{ Health problem/disability } & & & $-2.81^{* * *}$ & -0.51 & & & $-2.78^{* * *}$ & -0.52 \\
\hline & & & {$[-3.65,-1.97]$} & {$[-1.95,0.93]$} & & & {$[-3.63,-1.94]$} & {$[-1.95,0.92]$} \\
\hline \multirow[t]{2}{*}{ Education (ref=No quals) } & & & 0.00 & & & & 0.00 & \\
\hline & & & {$[0.00,0.00]$} & & & & {$[0.00,0.00]$} & \\
\hline Below GCSE & & & -0.09 & & & & -0.10 & \\
\hline
\end{tabular}


Housing (ref=owner)

0.00

$[0.00,0.00]$

Private rent

$-2.23^{* *}$

$[-3.82,-0.63]$

Social rent

$-5.16^{* * *}$

$[-6.70,-3.62]$

Family/friends

$-1.84$

$[-4.46,0.77]$

Ethnicity (ref=white)

0.00

$[0.00,0.00]$

$$
\begin{gathered}
2.33^{* * *} \\
{[1.51,3.14]}
\end{gathered}
$$

0.00

[0.00,0.00]

$-2.27^{* *}$

[-3.88,-0.67]

$-5.20^{* * *}$

$[-6.74,-3.65]$

$-2.02$

$[-4.65,0.60]$

0.00

$[0.00,0.00]$

$-1.46$ 
Asian

Black

Other

Marital status (ref=married)

Divorced

Widowed

Never married

Log house prices - MSOA

Log \% prof/managerial - MSOA

Log \% non-white - MSOA

Log population density - MSOA
$[-5.76,2.83]$

$[-5.74,2.89]$

3.05

$[-0.21,6.31]$

$-0.34$

$[-5.68,5.01]$

$-0.44$

$[-4.53,3.65]$

$[-4.52,3.72]$

0.00

$[0.00,0.00]$

0.55

$[-0.77,1.86]$

1.08

$[-0.83,3.00]$

$-2.11^{* *}$

$[-3.50,-0.72]$

$-0.31$

[-1.50,0.89]

$\begin{array}{cc}-0.72 & -3.30 \\ {[-2.76,1.31]} & {[-9.47,2.88]}\end{array}$

0.70

$[-0.98,2.39]$

$-0.04$

$[-0.66,0.58]$

$-0.69^{* * *}$
0.00

$[0.00,0.00]$

0.67

$[-0.65,1.98]$

1.11

$[-0.79,3.02]$

$-1.95^{* *}$

$[-3.35,-0.56]$

$-0.32$

$[-1.51,0.88]$

0.25

$[-1.73,2.24]$

$-3.35$

$[-9.52,2.82]$

0.03

$[-1.61,1.66]$

0.01

$[-0.60,0.62]$

$-0.70^{* * *}$ 
Notes: $95 \%$ confidence intervals in brackets. ${ }^{*} p<0.05,{ }^{* *} p<0.01,{ }^{* * *} p<0.001$. Estimates and $95 \%$ confidence intervals from linear regression models with wave fixed effects and standard errors clustered at MSOA level. RE $=$ models with individual random intercepts and region fixed effects, FE $=$ models with individual fixed effects. Sample size $=18,812$ observations across 9,406 respondents in 4,912 MSOAs. Individual level data from BES panel survey waves 1 (Feb 2014 ) and 4 (March 2015).

Unemployment benefit claims data from Nomis, house prices from ONS HPPSA, population density, diversity, and occupational class measures from 2011 Census. 
Table A4: Association between unemployment benefit claims at LA level and belief that unemployed responsible for their situation. Coefficients plotted in figure 2.

\begin{tabular}{|c|c|c|c|c|c|c|c|c|}
\hline \multirow[b]{3}{*}{ Model } & (1) & (2) & (3) & (4) & (5) & (6) & (7) & (8) \\
\hline & \multicolumn{2}{|c|}{ No covariates } & \multicolumn{2}{|c|}{ + Individual level } & \multicolumn{2}{|c|}{+ Area level } & \multicolumn{2}{|c|}{ All covariates } \\
\hline & $\mathrm{RE}$ & FE & $\mathrm{RE}$ & $\mathrm{FE}$ & $\mathrm{RE}$ & $\mathrm{FE}$ & RE & $\mathrm{FE}$ \\
\hline \multirow{2}{*}{$\begin{array}{l}\text { Unemployment benefit } \\
\text { claims - LA }\end{array}$} & $-0.68^{* *}$ & -0.08 & $-0.46^{*}$ & -0.09 & -0.28 & 0.11 & -0.06 & 0.10 \\
\hline & {$[-1.12,-0.24]$} & {$[-1.39,1.24]$} & {$[-0.90,-0.01]$} & {$[-1.40,1.23]$} & {$[-0.99,0.44]$} & {$[-1.26,1.48]$} & {$[-0.78,0.65]$} & {$[-1.26,1.47]$} \\
\hline \multirow[t]{2}{*}{ Subjective poverty risk } & & & $-1.45^{* * *}$ & -0.29 & & & $-1.46^{* * *}$ & -0.29 \\
\hline & & & {$[-1.74,-1.15]$} & {$[-0.77,0.19]$} & & & {$[-1.75,-1.16]$} & {$[-0.77,0.19]$} \\
\hline \multirow{2}{*}{$\begin{array}{l}\text { Economic activity } \\
\text { (ref=working) }\end{array}$} & & & 0.00 & 0.00 & & & 0.00 & 0.00 \\
\hline & & & {$[0.00,0.00]$} & {$[0.00,0.00]$} & & & {$[0.00,0.00]$} & {$[0.00,0.00]$} \\
\hline \multirow[t]{2}{*}{ Unemployed } & & & $-9.13^{* * *}$ & -0.64 & & & $-9.12^{* * *}$ & -0.68 \\
\hline & & & {$[-11.84,-6.42]$} & {$[-4.84,3.56]$} & & & {$[-11.83,-6.40]$} & {$[-4.86,3.50]$} \\
\hline \multirow[t]{2}{*}{ Education } & & & -1.64 & 2.04 & & & -1.60 & 2.01 \\
\hline & & & {$[-5.33,2.04]$} & {$[-3.19,7.26]$} & & & {$[-5.28,2.08]$} & {$[-3.22,7.23]$} \\
\hline \multirow[t]{2}{*}{ Retired } & & & -0.09 & -1.41 & & & -0.09 & -1.45 \\
\hline & & & {$[-1.25,1.08]$} & {$[-3.95,1.13]$} & & & {$[-1.25,1.07]$} & {$[-3.99,1.08]$} \\
\hline \multirow[t]{2}{*}{ Not in paid work } & & & $-6.02^{* * *}$ & -1.45 & & & $-6.05^{* * *}$ & -1.49 \\
\hline & & & {$[-7.33,-4.72]$} & {$[-4.16,1.27]$} & & & {$[-7.36,-4.74]$} & {$[-4.20,1.22]$} \\
\hline \multirow[t]{2}{*}{ Health problem/disability } & & & $-2.83^{* * *}$ & -0.50 & & & $-2.85^{* * *}$ & -0.49 \\
\hline & & & {$[-3.69,-1.98]$} & {$[-2.00,0.99]$} & & & {$[-3.70,-2.00]$} & {$[-1.99,1.00]$} \\
\hline \multirow[t]{2}{*}{ Education (ref=No quals) } & & & 0.00 & & & & 0.00 & \\
\hline & & & {$[0.00,0.00]$} & & & & {$[0.00,0.00]$} & \\
\hline
\end{tabular}


Below GCSE

GCSE

A-level

Undergraduate

Postgrad

Age

Female $(\mathrm{ref}=$ male $)$

Housing (ref=owner)

Private rent

Social rent

Family/friends

Ethnicity (ref=white)
$-0.04$

$[-2.04,1.96]$

1.33

$[-0.25,2.91]$

0.94

$[-0.65,2.53]$

$-2.31^{* *}$

$[-3.84,-0.78]$

$-4.50^{* * *}$

$[-6.45,-2.56]$

$-0.13^{* * *}$

$[-0.18,-0.08]$

$2.36^{* * *}$

$[1.49,3.23]$

0.00

$[0.00,0.00]$

$-2.23^{* *}$

$[-3.85,-0.62]$

$-5.45^{* * *}$

[-7.12,-3.79]

$-1.69$

$[-4.42,1.03]$

0.00

$[0.00,0.00]$
$-0.05$

$[-2.06,1.95]$

1.31

$[-0.27,2.89]$

0.89

$[-0.70,2.48]$

$-2.33^{* *}$

$[-3.87,-0.80]$

$-4.48^{* * *}$

$[-6.42,-2.54]$

$-0.13^{* * *}$

$[-0.18,-0.09]$

$2.34^{* * *}$

[1.48,3.21]

0.00

$[0.00,0.00]$

$-2.28^{* *}$

$[-3.89,-0.66]$

$-5.42^{* * *}$

$[-7.08,-3.76]$

$-1.86$

$[-4.58,0.87]$

0.00

$[0.00,0.00]$ 
Mixed

Asian

Black

Other

Marital status $(r e f=m a r r i e d)$

Divorced

Widowed

Never married

Children in $\mathrm{HH}$

Log house prices - LA

Log \% prof/managerial - LA

Log \% non-white - LA
$-1.57$

$[-6.14,2.99]$

2.67

$[-0.32,5.66]$

$-0.65$

$[-5.97,4.67]$

$-0.52$

$[-4.88,3.84]$

0.00

$[0.00,0.00]$

0.45

$[-0.83,1.73]$

1.03

$[-0.86,2.93]$

$-2.21^{* *}$

$[-3.64,-0.77]$

$-0.29$

$[-1.42,0.84]$
$-1.51$

$[-6.08,3.06]$

2.71

$[-0.32,5.75]$

$-0.69$

$[-5.99,4.60]$

$-0.74$

$[-5.10,3.63]$

0.00

$[0.00,0.00]$

0.51

$[-0.78,1.80]$

1.01

$[-0.89,2.90]$

$-2.10^{* *}$

$[-3.54,-0.66]$

$-0.33$

$[-1.45,0.80]$

$-0.27$

$[-3.36,2.83]$

$-11.11$

[-27.15,4.93]

0.95

$[-1.92,3.83]$

$-11.21$

$-0.25$

$[-3.29,2.79]$

0.16

$[-0.58,0.90]$
$-1.17$

$[-4.17,1.84]$

0.18

$[-0.56,0.92]$ 
$-0.82^{* *}$

$[-1.40,-0.23]$
$-0.83^{* *}$

$[-1.41,-0.25]$

Constant
$45.78^{* * *}$
$43.90^{* * *}$
$57.98^{* * *}$
$45.45^{* * *}$
$49.77^{* *}$
$[41.33,49.56]$
[16.25,83.29]

179.29

[-

$49.42^{* *}$

$[18.03,80.82]$

181.98

15.78,374.37]

Notes: $95 \%$ confidence intervals in brackets. ${ }^{*} p<0.05,{ }^{* *} p<0.01,{ }^{* * *} p<0.001$. Estimates and $95 \%$ confidence intervals from linear regression models with wave fixed

effects and standard errors clustered at LA level. RE = models with individual random intercepts and region fixed effects, FE = models with individual fixed effects. Sample size $=18,812$ observations across 9,406 respondents in 343 LAs. Individual level data from BES panel survey waves 1 (Feb 2014) and 4 (March 2015). Unemployment benefit claims data from Nomis, house prices from ONS HPPSA, population density, diversity, and occupational class measures from 2011 Census. 
Table A5: Association between unemployment benefit claims and perceived welfare dependency. Coefficients plotted in figure 2.

\begin{tabular}{|c|c|c|c|c|c|c|c|c|}
\hline \multirow{4}{*}{$\begin{array}{l}\text { Area of measurement } \\
\text { Model }\end{array}$} & (1) & (2) & (3) & (4) & (5) & (6) & (7) & (8) \\
\hline & \multicolumn{4}{|c|}{ MSOA } & \multicolumn{4}{|c|}{ LA } \\
\hline & \multicolumn{2}{|c|}{ No covariates } & \multicolumn{2}{|c|}{ All covariates } & \multicolumn{2}{|c|}{ No covariates } & \multicolumn{2}{|c|}{ All covariates } \\
\hline & RE & $\mathrm{FE}$ & $\mathrm{RE}$ & $\mathrm{FE}$ & RE & $\mathrm{FE}$ & RE & $\mathrm{FE}$ \\
\hline \multirow{2}{*}{$\begin{array}{l}\text { Unemployment benefit claims - } \\
\text { MSOA }\end{array}$} & $-0.83^{* * *}$ & -0.23 & $-0.76^{* *}$ & -0.23 & & & & \\
\hline & {$[-1.20,-0.46]$} & {$[-1.05,0.60]$} & {$[-1.28,-0.24]$} & {$[-1.06,0.60]$} & & & & \\
\hline \multirow{2}{*}{$\begin{array}{l}\text { Unemployment benefit claims - } \\
\text { LA }\end{array}$} & & & & & $-0.88^{* *}$ & -0.75 & $-1.18^{* *}$ & -0.72 \\
\hline & & & & & {$[-1.50,-0.27]$} & {$[-1.88,0.37]$} & {$[-2.04,-0.32]$} & {$[-1.87,0.42]$} \\
\hline \multirow[t]{2}{*}{ Subjective poverty risk } & & & $-0.90^{* * *}$ & 0.19 & & & $-0.92^{* * *}$ & 0.18 \\
\hline & & & {$[-1.24,-0.56]$} & {$[-0.25,0.62]$} & & & {$[-1.23,-0.61]$} & {$[-0.22,0.58]$} \\
\hline \multirow[t]{2}{*}{ Economic activity (ref=working) } & & & 0.00 & 0.00 & & & 0.00 & 0.00 \\
\hline & & & {$[0.00,0.00]$} & {$[0.00,0.00]$} & & & {$[0.00,0.00]$} & {$[0.00,0.00]$} \\
\hline \multirow[t]{2}{*}{ Unemployed } & & & $-7.97^{* * *}$ & -1.78 & & & $-8.01^{* * *}$ & -1.76 \\
\hline & & & {$[-11.07,-4.88]$} & {$[-5.57,2.01]$} & & & {$[-11.14,-4.88]$} & {$[-5.48,1.97]$} \\
\hline \multirow[t]{2}{*}{ Education } & & & $-7.38^{* * *}$ & -4.05 & & & $-7.17^{* * *}$ & -4.06 \\
\hline & & & {$[-11.31,-3.45]$} & {$[-8.82,0.73]$} & & & {$[-11.00,-3.33]$} & {$[-8.64,0.52]$} \\
\hline \multirow[t]{2}{*}{ Retired } & & & -0.70 & -0.42 & & & -0.69 & -0.41 \\
\hline & & & {$[-1.97,0.57]$} & {$[-2.53,1.69]$} & & & {$[-1.95,0.57]$} & {$[-2.49,1.67]$} \\
\hline \multirow[t]{2}{*}{ Not in paid work } & & & $-10.16^{* * *}$ & $-3.53^{*}$ & & & $-10.15^{* * *}$ & $-3.52^{*}$ \\
\hline & & & {$[-11.97,-8.36]$} & {$[-6.29,-0.76]$} & & & {$[-12.10,-8.19]$} & {$[-6.37,-0.67]$} \\
\hline \multirow[t]{2}{*}{ Health problem/disability } & & & $-2.80^{* * *}$ & -0.71 & & & $-2.81^{* * *}$ & -0.70 \\
\hline & & & {$[-3.77,-1.83]$} & {$[-2.05,0.64]$} & & & {$[-3.75,-1.88]$} & {$[-2.02,0.62]$} \\
\hline Education (ref=No quals) & & & 0.00 & & & & 0.00 & \\
\hline
\end{tabular}


Below GCSE

GCSE

A-level

Undergraduate

Postgrad

Age

Female (ref=male)

Housing (ref=owner)

Private rent

Social rent

Family/friends
$-1.69$

$[-4.33,0.94]$

$-0.21$

$[-2.17,1.75]$

$-2.69^{*}$

[-4.76,-0.61]

$-11.64^{* * *}$

$[-13.66,-9.61]$

$-18.24^{* * *}$

[-20.82,-

15.65]

$-0.09^{* *}$

[-0.16,-0.03]

$2.53^{* * *}$

$[1.46,3.60]$

0.00

$[0.00,0.00]$

$-5.85^{* *}$

[-8.07,-3.62]

$-10.39^{* * *}$

$[-12.38,-8.41]$

$-2.60$

$[-6.03,0.83]$
$-1.65$

$[-4.13,0.83]$

$-0.12$

$[-2.15,1.91]$

$-2.53^{*}$

$[-4.63,-0.43]$

$-11.50^{* * *}$

[-13.55,-9.44]

$-18.13^{* * *}$

[-20.94,-

15.32]

$-0.09^{* *}$

$[-0.15,-0.03]$

$2.56^{* * *}$

[1.42,3.69]

0.00

$[0.00,0.00]$

$-5.93^{* * *}$

$[-8.01,-3.84]$

$-10.62^{* * *}$

$[-12.64,-8.60]$

$-2.35$

$[-5.94,1.24]$ 
Ethnicity (ref=white)

Mixed

Asian

Black

Other

Marital status (ref=married)

Divorced

Widowed

Never married

Children in $\mathrm{HH}$

Log house prices - MSOA

Log \% prof/managerial - MSOA
0.00

$[0.00,0.00]$

$-4.59$

$[-11.13,1.95]$

$11.56^{* *}$

[7.50,15.62]

2.99

$[-3.65,9.63]$

$-0.08$

$[-7.16,7.00]$

0.00

$[0.00,0.00]$

$-1.10$

$[-2.85,0.65]$

$2.98^{*}$

$[0.50,5.46]$

$-2.69^{* *}$

$[-4.54,-0.83]$

$-1.33$

$[-2.91,0.26]$

$-0.37$

$[-2.95,2.21]$

$-2.34$

$[-7.76,3.08]$
0.00

$[0.00,0.00]$

$-4.86$

$[-12.16,2.43]$

$10.89^{* *}$

$[6.30,15.48]$

2.75

$[-4.94,10.44]$

$-0.40$

$[-7.97,7.17]$

0.00

$[0.00,0.00]$

$-1.28$

$[-3.10,0.53]$

$2.85^{*}$

$[0.39,5.31]$

$-2.91^{*}$

$[-4.66,-1.16]$

$-1.37$

$[-2.95,0.20]$

$-1.83$

$[-4.00,0.33]$ 
Log population density - LA

Constant

Notes: $95 \%$ confidence intervals in brackets. ${ }^{*} p<0.05,{ }^{* *} p<0.01,{ }^{* * *} p<0.001$. Estimates and $95 \%$ confidence intervals from linear regression models with wave fixed effects and standard errors clustered at area level (MSOA or LA). RE = models with individual random intercepts and region fixed effects, $\mathrm{FE}=$ models with individual fixed effects. Sample size $=18,664$ observations across 9,400 respondents in 4,911 MSOAs and 343 LAs. Individual level data from BES panel survey waves 1 (Feb 2014 ) and 4 (March 2015). Unemployment benefit claims data from Nomis, house prices from ONS HPPSA, population density, diversity, and occupational class measures from 2011 Census. 
Table A6: Association between unemployment benefit claims and belief that unemployed responsible for situation conditional on economic advantage. Estimated marginal means plotted in figure 3.

\begin{tabular}{|c|c|c|c|c|c|c|}
\hline & (1) & (2) & (3) & (4) & (5) & (6) \\
\hline Area of measurement & MSOA & LA & MSOA & LA & MSOA & LA \\
\hline UB claims - MSOA & -0.278 & & 0.008 & & $-1.004^{* * *}$ & \\
\hline & {$[-0.62,0.06]$} & & {$[-0.50,0.52]$} & & {$[-1.32,-0.69]$} & \\
\hline UB claims - LA & & $\begin{array}{c}-0.167 \\
{[-0.71,0.37]}\end{array}$ & & $\begin{array}{c}0.075 \\
{[-0.64,0.79]}\end{array}$ & & $\begin{array}{c}-1.092^{* * *} \\
{[-1.60,-0.58]}\end{array}$ \\
\hline
\end{tabular}

Unemployed

$-7.440^{* *}$

$-0.71,0.37]$

$[-0.64,0.79]$

$[-1.60,-0.58]$

$[-12.19,-2.69] \quad[-14.73,-3.20]$

Not in labour force

$-0.374$

$[-14.73,-3.20]$

$[-1.61,0.86]$

$-0.294$

$-1.118$

Unemployed X UB

claims - MSOA

$[-2.38,0.14]$

Not in labour force $X$

$-1.098^{* * *}$

UB claims - MSOA

$[-1.55,-0.65]$

Unemployed X UB

claims - LA

Not in labour force $X$

$-1.015^{* * *}$

UB claims - LA

$[-1.59,-0.44]$

Subj. poverty risk
$-1.197^{* * *}$
$-1.195^{* * *}$
$[-1.68,-0.72]$
$[-1.78,-0.61]$ 
UB claims - MSOA X

Subj. poverty risk

UB claims - LA X Subj.

poverty risk

Degree

Degree X UB claims -

MSOA

Degree X UB claims -

LA

Constant

$46.335^{* * *}$

[44.82,47.85]

$46.003^{* * *}$

$[44.28,47.72]$

[46.81,50.37]

$[-0.40,-0.06]$

$-0.245^{*}$

[-0.47,-0.02]

$-2.566^{* *}$

Notes: $95 \%$ confidence intervals in brackets. ${ }^{*} p<0.05,{ }^{* *} p<0.01,{ }^{* * *} p<0.001$. Coefficients and $95 \%$ confidence intervals from linear regression models with random intercepts for individuals, wave and region fixed effects, and standard errors clustered at area level (either MSOA or LA). Sample size $=18,812$ observations across 9,406 respondents in 343 LAs. Individual level data from BES panel survey waves 1 (Feb 2014) and 4 (March 2015). Unemployment benefit claims data from Nomis.
$[-3.85,-1.29]$

0.403

$[-0.07,0.87]$

$[0.37,1.50]$

$\begin{array}{cc}47.103^{* * *} & 47.307^{* * *} \\ {[45.59,48.61]} & {[45.62,49.00]}\end{array}$

$48.527^{* * *}$

$[-5.37,-2.10]$

$0.934^{* *}$

andom 
Figure A1: Association between unemployment benefit claims and belief that unemployed responsible for situation conditional on economic advantage with individual and area level controls.

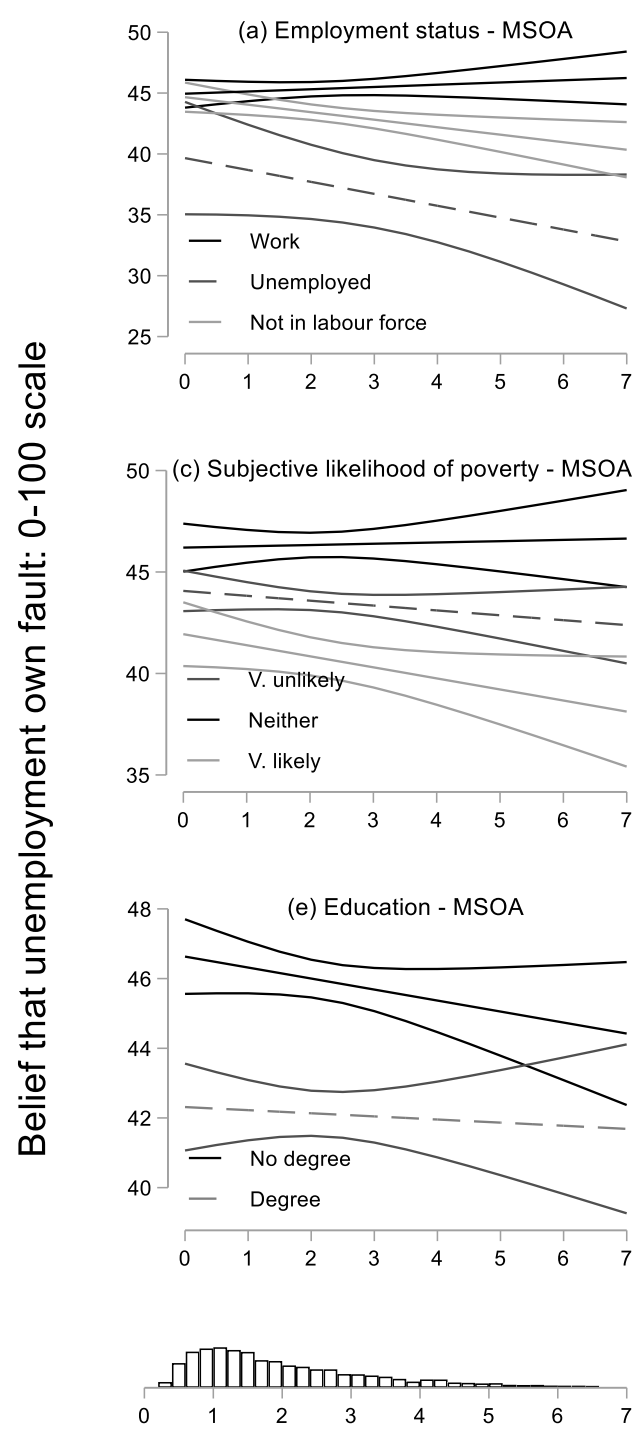

UB claims \%: MSOA

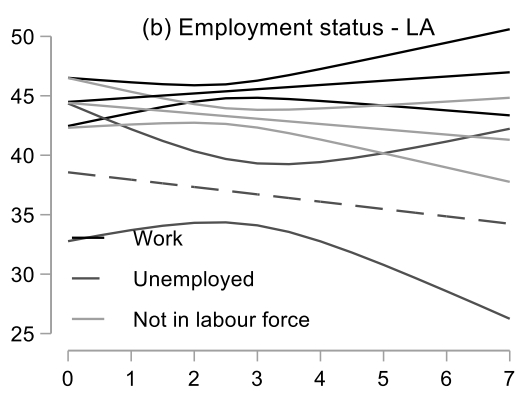

(d) Subjective likelihood of poverty - LA

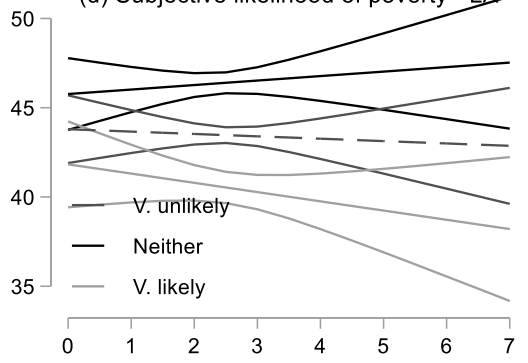

(f) Education - LA

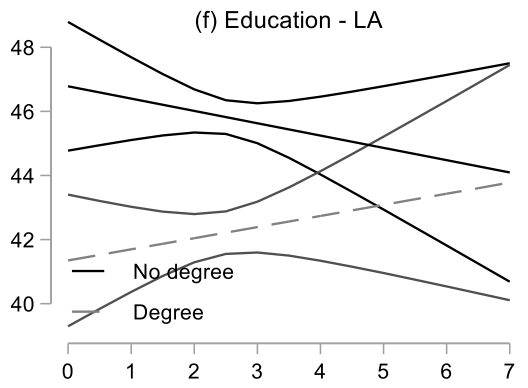

$\begin{array}{llllllll}0 & \\ 0 & 1 & 2 & 3 & 4 & 5 & 6 & 7\end{array}$

UB claims \%: LA

Notes: Estimated marginal means and $95 \%$ confidence intervals from models in table A7 below. See notes for details. 
Table A7: Association between unemployment benefit claims and belief that unemployed responsible for situation conditional on economic advantage with individual and area level controls. Estimated marginal means plotted in figure A1.

\begin{tabular}{|c|c|c|c|c|c|c|}
\hline & (1) & (2) & (3) & (4) & (5) & (6) \\
\hline Area of measurement & MSOA & LA & MSOA & LA & MSOA & LA \\
\hline UB claims - MSOA & $\begin{array}{c}0.185 \\
{[-0.25,0.62]}\end{array}$ & & $\begin{array}{c}0.216 \\
{[-0.37,0.80]}\end{array}$ & & $\begin{array}{c}-0.316 \\
{[-0.73,0.10]}\end{array}$ & \\
\hline UB claims - LA & & $\begin{array}{c}0.356 \\
{[-0.43,1.14]}\end{array}$ & & $\begin{array}{c}0.444 \\
{[-0.47,1.35]}\end{array}$ & & $\begin{array}{c}-0.384 \\
{[-1.14,0.37]}\end{array}$ \\
\hline Unemployed & $\begin{array}{c}-5.288^{*} \\
{[-9.93,-0.64]}\end{array}$ & $\begin{array}{c}-5.922^{*} \\
{[-11.67,-0.17]}\end{array}$ & & & & \\
\hline Not in labour force & $\begin{array}{c}-0.284 \\
{[-1.60,1.03]}\end{array}$ & $\begin{array}{c}-0.080 \\
{[-1.72,1.56]}\end{array}$ & & & & \\
\hline Unemployed X UB claims - MSOA & $\begin{array}{c}-1.163 \\
{[-2.38,0.06]}\end{array}$ & & & & & \\
\hline Not in labour force X UB claims - MSOA & $\begin{array}{c}-0.801^{* * *} \\
{[-1.24,-0.36]}\end{array}$ & & & & & \\
\hline Unemployed X UB claims - LA & & $\begin{array}{c}-0.974 \\
{[-2.81,0.86]}\end{array}$ & & & & \\
\hline Not in labour force X UB claims - LA & & $\begin{array}{c}-0.800^{* *} \\
{[-1.35,-0.25]}\end{array}$ & & & & \\
\hline Subj. poverty risk & $\begin{array}{c}-1.525^{* * *} \\
{[-1.84,-1.20]}\end{array}$ & $\begin{array}{c}-1.563^{* * *} \\
{[-1.86,-1.27]}\end{array}$ & $\begin{array}{c}-1.066^{* * *} \\
{[-1.55,-0.58]}\end{array}$ & $\begin{array}{c}-0.985^{* * *} \\
{[-1.56,-0.41]}\end{array}$ & $\begin{array}{c}-1.421^{* * *} \\
{[-1.74,-1.10]}\end{array}$ & $\begin{array}{c}-1.452^{* * *} \\
{[-1.75,-1.16]}\end{array}$ \\
\hline UB claims - MSOA X Subj. poverty risk & & & $\begin{array}{c}-0.152 \\
{[-0.32,0.01]}\end{array}$ & & & \\
\hline
\end{tabular}


UB claims - LA X Subj. poverty risk

Degree

Degree X UB claims - MSOA

Degree X UB claims - LA

Health problem/disability

Education (ref=No quals)

Below GCSE

GCSE

A-level

Undergraduate

Postgrad

Age
$-0.192$

$[-0.41,0.02]$

$\begin{array}{cc}-4.319^{* * *} & -5.433^{* * *} \\ {[-5.59,-3.05]} & {[-7.03,-3.84]}\end{array}$

0.226

$[-0.22,0.67]$

$$
0.731^{* *}
$$

$[0.18,1.28]$

$\begin{array}{cc}-3.074^{* * *} & -3.168^{* * *} \\ {[-3.92,-2.23]} & {[-4.02,-2.32]} \\ 0.000 & 0.000 \\ {[0.00,0.00]} & {[0.00,0.00]}\end{array}$

$-2.782^{* * *}$
$[-3.63,-1.94]$
0.000
$[0.00,0.00]$

$-2.850^{* * *}$

$[-3.70,-2.00]$

$-2.801^{* * *}$

$[-3.65,-1.96]$

$-2.868^{* * *}$

[-3.72,-2.02]

0.000

$[0.00,0.00]$

-0.362
$[-2.58,1.86]$

-0.199
$-2.23,1.83]$

$-0.093$

$[-2.30,2.11]$

$-0.050$

$[-2.06,1.96]$

1.016
$-0.60,2.63$

1.157

$[-0.42,2.74]$

1.228

$[-0.38,2.84]$

1.302

$[-0.28,2.88]$

0.630

0.844

$[-0.75,2.43]$

0.771

$[-0.88,2.42]$

0.891

$[-0.70,2.48]$

$-2.556^{* *}$

$[-4.13,-0.98]$

$-2.259^{* *}$

$-2.547^{* *}$

[-4.12,-0.98]

$-2.333^{* *}$

$[-3.79,-0.72]$

$-4.722^{* * *}$

$-4.413^{* * *}$

[-6.36,-2.47]

$-4.700^{* * *}$

$[-6.62,-2.78]$

$-4.475^{* * *}$

$[-6.64,-2.80]$

$-0.077^{* * *}$

$[-0.12,-0.03]$
$-0.137^{* * *}$
$[-0.18,-0.09]$
$[-6.41,-2.54]$

$-0.134^{* * *}$

$[-0.18,-0.08]$
$-0.138^{* * *}$

$[-0.18,-0.09]$
$-0.133^{* * *}$

[-0.18,-0.08] 


\begin{tabular}{|c|c|c|c|c|c|c|}
\hline Male & $\begin{array}{c}0.000 \\
{[0.00,0.00]}\end{array}$ & $\begin{array}{c}0.000 \\
{[0.00,0.00]}\end{array}$ & $\begin{array}{c}0.000 \\
{[0.00,0.00]}\end{array}$ & $\begin{array}{c}0.000 \\
{[0.00,0.00]}\end{array}$ & $\begin{array}{c}0.000 \\
{[0.00,0.00]}\end{array}$ & $\begin{array}{c}0.000 \\
{[0.00,0.00]}\end{array}$ \\
\hline Female (ref=male) & $\begin{array}{c}2.176^{* * *} \\
{[1.36,2.99]}\end{array}$ & $\begin{array}{c}2.185^{* * *} \\
{[1.32,3.05]}\end{array}$ & $\begin{array}{c}2.328^{* * *} \\
{[1.51,3.15]}\end{array}$ & $\begin{array}{c}2.350^{* * *} \\
{[1.48,3.22]}\end{array}$ & $\begin{array}{c}2.351^{* * *} \\
{[1.54,3.16]}\end{array}$ & $\begin{array}{c}2.349^{* * *} \\
{[1.48,3.22]}\end{array}$ \\
\hline Housing (ref=owner) & $\begin{array}{c}0.000 \\
{[0.00,0.00]}\end{array}$ & $\begin{array}{c}0.000 \\
{[0.00,0.00]}\end{array}$ & $\begin{array}{c}0.000 \\
{[0.00,0.00]}\end{array}$ & $\begin{array}{c}0.000 \\
{[0.00,0.00]}\end{array}$ & $\begin{array}{c}0.000 \\
{[0.00,0.00]}\end{array}$ & $\begin{array}{c}0.000 \\
{[0.00,0.00]}\end{array}$ \\
\hline Social rent & $\begin{array}{c}-5.625^{* * *} \\
{[-7.18,-4.07]}\end{array}$ & $\begin{array}{c}-5.945^{* * *} \\
{[-7.62,-4.27]}\end{array}$ & $\begin{array}{c}-5.158^{* * *} \\
{[-6.70,-3.61]}\end{array}$ & $\begin{array}{c}-5.417^{* * *} \\
{[-7.07,-3.76]}\end{array}$ & $\begin{array}{c}-5.178^{* * *} \\
{[-6.71,-3.64]}\end{array}$ & $\begin{array}{c}-5.426^{* * *} \\
{[-7.07,-3.79]}\end{array}$ \\
\hline Family/friends & $\begin{array}{c}-1.457 \\
{[-4.08,1.17]}\end{array}$ & $\begin{array}{c}-1.282 \\
{[-4.00,1.44]}\end{array}$ & $\begin{array}{c}-2.047 \\
{[-4.67,0.58]}\end{array}$ & $\begin{array}{c}-1.872 \\
{[-4.59,0.85]}\end{array}$ & $\begin{array}{c}-1.892 \\
{[-4.52,0.73]}\end{array}$ & $\begin{array}{c}-1.702 \\
{[-4.43,1.03]}\end{array}$ \\
\hline Asian & $\begin{array}{c}3.243^{*} \\
{[0.00,6.48]}\end{array}$ & $\begin{array}{c}2.914 \\
{[-0.08,5.90]}\end{array}$ & $\begin{array}{c}3.058 \\
{[-0.20,6.32]}\end{array}$ & $\begin{array}{c}2.731 \\
{[-0.30,5.77]}\end{array}$ & $\begin{array}{c}2.840 \\
{[-0.39,6.07]}\end{array}$ & $\begin{array}{c}2.495 \\
{[-0.50,5.49]}\end{array}$ \\
\hline Black & $\begin{array}{c}-0.388 \\
{[-5.77,4.99]}\end{array}$ & $\begin{array}{c}-0.669 \\
{[-5.95,4.62]}\end{array}$ & $\begin{array}{c}-0.318 \\
{[-5.68,5.04]}\end{array}$ & $\begin{array}{c}-0.683 \\
{[-5.99,4.62]}\end{array}$ & $\begin{array}{c}-0.405 \\
{[-5.77,4.96]}\end{array}$ & $\begin{array}{c}-0.675 \\
{[-6.01,4.66]}\end{array}$ \\
\hline Other & $\begin{array}{c}-0.886 \\
{[-4.93,3.16]}\end{array}$ & $\begin{array}{c}-1.208 \\
{[-5.50,3.08]}\end{array}$ & $\begin{array}{c}-0.431 \\
{[-4.52,3.65]}\end{array}$ & $\begin{array}{c}-0.742 \\
{[-5.10,3.62]}\end{array}$ & $\begin{array}{c}-0.467 \\
{[-4.56,3.62]}\end{array}$ & $\begin{array}{c}-0.785 \\
{[-5.12,3.55]}\end{array}$ \\
\hline Marital status (ref=married) & 0.000 & 0.000 & 0.000 & 0.000 & 0.000 & 0.000 \\
\hline
\end{tabular}




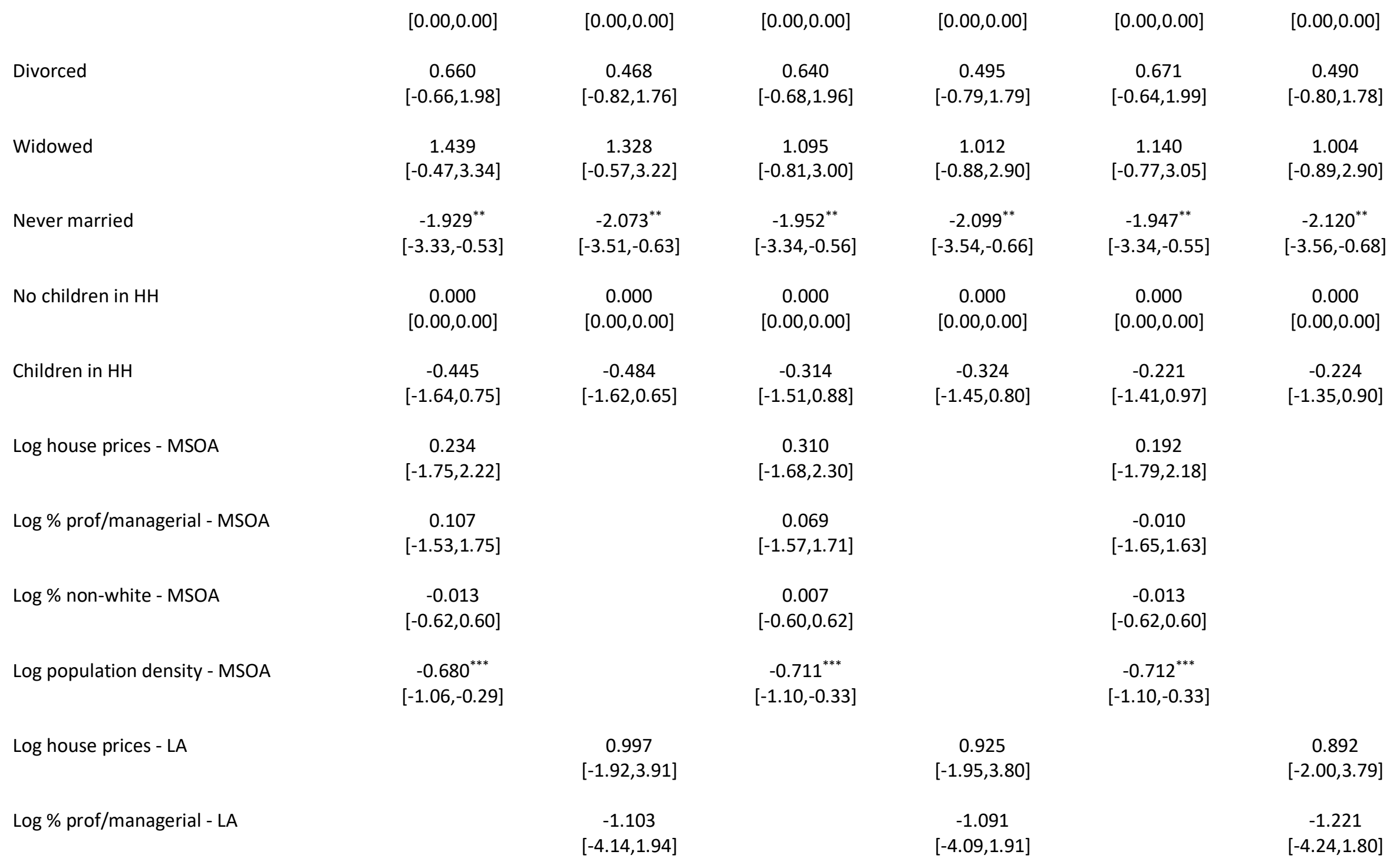


Log \% non-white - LA

Log population density - LA

Economic activity (ref=working)

Unemployed

Education

Retired

Not in paid work

Constant

$53.239^{* * *}$

$[30.86,75.62]$
0.137

$[-0.61,0.89]$

$-0.802^{* *}$

$[-1.39,-0.22]$
0.173

$[-0.57,0.92]$

$-0.846^{* *}$

$[-1.43,-0.27]$

$\begin{array}{cc}0.000 & 0.000 \\ {[0.00,0.00]} & {[0.00,0.00]}\end{array}$

$-9.047^{* * *}$

$[-11.76,-6.34]$

$-9.050^{* * *}$

$[-11.80,-6.22]$

\section{$-1.733$}

$[-5.38,1.91]$

$-0.107$

$[-1.16,0.95]$

$-6.022^{* * *}$

$[-7.45,-4.60]$

-1.565
$[-5.25,2.12]$

$-0.075$

[-1.24,1.09]

$-6.005^{* * *}$

$[-7.31,-4.70]$
[-11.84,-6.26]

$-1.719$

$[-5.36,1.92]$

$-0.108$

$[-1.16,0.94]$

$-6.041^{* * *}$

$[-7.47,-4.62]$
0.163

[-0.59,0.92]

$-0.842^{* *}$

$[-1.43,-0.26]$

0.000

$[0.00,0.00]$

$-9.022^{* * *}$

[-11.74,-6.31]

$-1.554$

$[-5.22,2.12]$

$-0.078$

$[-1.25,1.09]$

$-5.999^{* * *}$

[-7.31,-4.69]

\begin{tabular}{|c|c|c|c|c|c|c|}
\hline Constant & $\begin{array}{c}53.239^{* * *} \\
{[30.86,75.62]}\end{array}$ & $\begin{array}{c}45.472^{* *} \\
{[13.59,77.35]}\end{array}$ & $\begin{array}{c}54.589^{* * *} \\
{[32.16,77.02]}\end{array}$ & $\begin{array}{c}48.432^{* *} \\
{[16.97,79.89]}\end{array}$ & $\begin{array}{c}58.219^{* * *} \\
{[35.87,80.57]}\end{array}$ & $51.902^{* *}$ \\
\hline
\end{tabular}
random intercepts for individuals, wave and region fixed effects, and standard errors clustered at area level (either MSOA or LA). Sample size $=18,812$

observations across 9,406 respondents in 343 LAs. Individual level data from BES panel survey waves 1 (Feb 2014 ) and 4 (March 2015 ). Unemployment benefit claims data from Nomis, house prices from ONS HPPSA, population density, diversity, and occupational class measures from 2011 Census. 